\title{
Sklářský výrobní okruh z 2. poloviny 13. století u Jilmové v Krušných horách Přínos analytických metod pro poznání technologie výroby středověkého skla v Čechách
}

\author{
The glass production area near Jilmová in the Ore Mountains \\ from the second half of the $13^{\text {th }}$ century \\ The contribution of analytical methods for studying glass \\ production technology in medieval Bohemia
}

\author{
Eva Černá - Zuzana Zlámalová Cílová - \\ Tomáš Vaculovič - Veronika Faltusová
}

Studie obsahuje nejnovějši poznatky o výrobě skla na počátku vrcholného středověku v jednom z nejstarších sklárských výrobních okruhů v Krušných horách, který sestává ze tř́ skláren situovaných ve vrcholových partiich hor. Jsou v ní prezentovány archeologické prameny získané terénními výzkumy lokalit Jilmová I, II a III. Pozornost je zaměřna na nálezy specifické pro sklářská výrobní centra. Jsou to především zlomky technické keramiky - sklářské pánve, kelímky a odpad doprovázející jednotlivé fáze výroby skla. Klasický typologicko-morfologický rozbor doprovází detailní výzkum archeometrický. Výsledky spektrometrických analýz (XRF, XRD, SEM-EDS a LA-ICP-MS) rozšírily výpovědní hodnotu archeologických nálezů a umožnily zpřesnit dosavadní poznatky o technologii výroby skla ve 2. polovině 13. století.

sklárna - středověk - sklářská pec - sklářské suroviny - sklářský kmen - pánev - popel - chemické složení

The study contains the latest knowledge concerning glass production at the beginning of the High Middle Ages in one of the oldest glass production areas in the Ore Mountains consisting of three glassworks located in the upper reaches of the mountains. The work presents archaeological sources obtained in excavations at the Jilmová I, II and III sites, with attention being focused on finds specific to glass production centres, i.e., mainly fragments of technical ceramics - melting pots, crucibles and the waste accompanying various stages of glass production. The classic typological-morphological analysis is accompanied by a detailed archaeometric analysis. The results of spectrometric analyses (XRF, XRD, SEM-EDS and $L A-I C P-M S$ ) expand the informative value of archaeological finds and help refine existing knowledge of glass production technology in the second half of the $13^{\text {th }}$ century.

glassworks - Middle Ages - glass furnace - glassmaking raw materials - glass batch - pot - ash - chemical analyses

\section{1. Úvod}

Z archeologických nálezo̊, které máme v současné době k dispozici je zřejmé, že znalost výroby skla z primárních surovin se dostala do Čech na počátku vrcholného středověku. Do té doby existovaly na území Čech a Moravy s velkou mírou pravděpodobnosti pouze sklářské dílny vyrábějící drobné skleněné ozdoby (korálky a kroužky) z dovezeného surového skla, tzn. sekundární centra výroby. Nasvědčují tomu prozatím jen neprrímé důkazy 


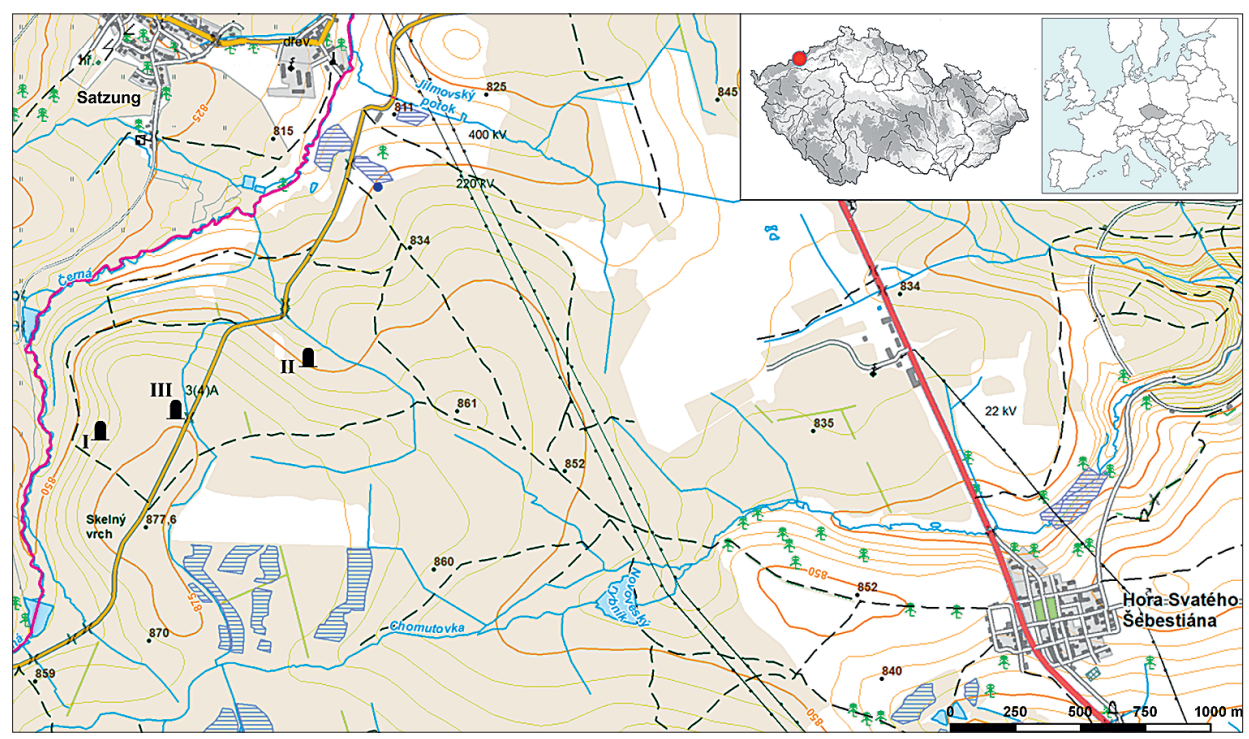

Obr. 1. Výsek mapy s vyznačením poloh skláren u zaniklé obce Jilmová, okr. Chomutov.

Fig. 1. Map showing the location of the glassworks near the defunct village of Jilmová, Chomutov district.

a indicie z období 11. a 12. století (srov. Himmelová-Měř́nský 1987, 129-134; Sedláčková-Zapletalová 2012, 542; Zavřel 2003, 718-735). I z písemných pramenů lze soudit, že českému prostředí na sklonku raného středověku byla práce se sklem známa (srov. Hejdová - Nechvátal 1967, 433-498 ad.) a že též v Čechách, obdobně jako jinde v Evropě, se na uchovávání znalostí sklářských technologií podílelo klášterní prostředí. Sporadičnost dokladů domácí výroby skla v raném středověku nedovoluje spolehlivě rozpoznat vazbu mezi raně středověkými sklářskými dílnami a sklárnami 13.-15. století; prozatím se jeví reálnější diskontinuita vývoje sklářského řemesla (naposledy Černá 2016).

Krušné hory patřily ve středověku k významným sklářským oblastem. V historické literatuře ze sklonku 19. a 1. poloviny 20. století pojednávající o sklářství ve středověkých Čechách však bylo Krušnohoří opomíjeno (Marě̌ 1893; Jiř́k 1934). Situace se změnila v 80. letech 20. století, kdy se krušnohorská krajina dostala do hledáčku mosteckých archeologů. Jedním z podnětů zvýšeného zájmu byl fatální dopad ekologické katastrofy na lesní krajinu. Působením průmyslových emisí docházelo od 70. let k odumírání lesů, jež bylo zapotřebí odtěžit a nahradit novými porosty. Obojí znamenalo velkou hrozbu pro archeologická naleziště, která bylo nutno včas lokalizovat a zdokumentovat. Pozornost byla věnována přednostně genezi domácího sklářského řemesla a jeho vývoji v průběhu 13.-15. století, souběžně byly sledovány a evidovány i stopy dalších výrobních aktivit ovlivňujících postup zemědělského osídlení do dříve pusté horské krajiny (Černá - Klír 2014). Intenzivní archeologická prospekce i záchranné výzkumy skláren přinesly množství nálezů - movitých i nemovitých - do té doby neznámých, které významně přispěly k poznání geneze a vývoje krušnohorského sklářství (Černá 1990; 1991; 1995; 1996).

Nové objevy zaniklých lokalit, včetně poznatků o jejich situování v krajině, umožnily rozpoznat sít skláren, definovat samostatné výrobní okruhy a současně poznat i jejich vnitřní 
strukturu. Ve východní části krušnohorského masivu je doloženo minimálně šest takových seskupení (Černá 2016, obr. 122); tři leží v okrese Chomutov: mezi Přísečnicí a Výsluním (1), u Jilmové (2) a Bečova (3); dvě v okrese Most: v okolí Brandova (4) a Mníšku (5); jeden na Teplicku: u Moldavy (6). Otázkou je, zda součástí posledního výrobního okruhu byly rovněž dvě sklárny objevené v údolí Křižanovského potoka. ${ }^{1}$

Z výše uvedených výrobních center patří k nejstarším sklárny u Jilmové. Tamější okruh tvoří tři lokality (obr. 1) ležící ve vrcholových partiích Skelného vrchu, v blízkosti západní větve dálkové komunikace zmiňované v písemných pramenech k r. 1143 jako semita bohemica směřující z vnitrozemí Čech přes Chomutov do oblastí kolem Saské Kamenice (srov. Černá - Velímský 1993; Černá 1998). Ve středověkých písemných pramenech nejsou zdejší sklárny zmiňovány. Jedinou indicií o jejich dávné existenci jsou oronyma (Vordere Glasberg, Hintere Glasberg, Skelný vrch) zaznamenaná na některých zeměpisných mapách historických i současných (obr. 2: $a-b$ ). Podle charakteru nalezených zlomků užitkové keramiky (struktury hlinitého materiálu, stupně výpalu i dalších technologických i morfologických znaků) existovaly všechny tři lokality v průběhu 2. poloviny 13. století (blíže Černá 2016, 80, 87, 92). Vznik sklářských center u Jilmové souvisí s hospodářsko-společenskými změnami ve 13. století, potažmo s využitím potenciálu tamější lesnaté krajiny. Středověké sklárny ve východní části Krušných hor zároveň představují cenný zdroj poznatků o osidlování horské krajiny. ${ }^{2}$

Sklárny na katastru dnes již neexistující obce Jilmová (Ulmbach) byly lokalizovány systematickými povrchovými průzkumy ve druhé polovině 80 . let 20. století v lesních porostech na SSZ od Hory sv. Šebestiána (Sebastiansberg). Krátce po jejich objevení, v letech 1985-1988, se uskutečnily záchranné archeologické výzkumy. Nejvíce nálezů pochází ze sklárny Jilmová I, jejíž výrobní areál byl v úplnosti prozkoumán. Nálezový soubor ze sklárny Jilmová II je podstatně chudší, nebot' v rámci záchranného výzkumu byla realizována jen nevelká zjišt'ovací sonda položená v místech dvou výrobních objektů indikovaných geofyzikálním průzkumem. Obdobně nevelké množství nálezů máme k dispozici ze třetí sklárny, z Jilmové III, jejíž areál byl totálně zničen skrývkami pro novodobou lesní výsadbu. Žádná z lokalit neposkytla zlomky hotových výrobků či polotovarů, takže jejich sortiment zůstává nepoznán. Tedy alespoň prozatím, nebot' není vyloučeno, že prř́činou absence zlomků hotových výrobků by mohl být malý rozsah archeologického výzkumu sklárny Jilmová II (viz níže). Právě ta by totiž mohla být, a to jak podle terénních zjištění, tak podle dosavadních znalostí o struktuře výrobních okruhů, sklárnou ,mateřskou“, v níž se sklo nejen tavilo, ale též zpracovávalo.

Archeologické nálezy z výzkumů všech tří skláren byly stručně publikovány již na sklonku 80. let (Černá 1988; 1989; 1991). Obsahovaly výsledky klasifikace pramenné základny z hlediska typologicko-morfologického, současně však přinesly otázky, z nichž některé, především stran technologie výroby skla, zůstávají dodnes bez uspokojivé odpovědi. Velký otazník se například váže k produkci skláren z hlediska vyráběných druhů, tvarů i chemického složení skel.

\footnotetext{
${ }^{1}$ Vzhledem k jejich předběžnému datování do 13 . století i topograficko-geografickým odlišnostem je pravděpodobněǰší, že představují další samostatně fungující okruh (Černá - Lissek - Plachý 2018).

${ }^{2}$ Problematikou kolonizace střední části Krušných hor na základě výpovědi písemných pramenů se zabýval T. Velímský (1998, 81-106).
} 

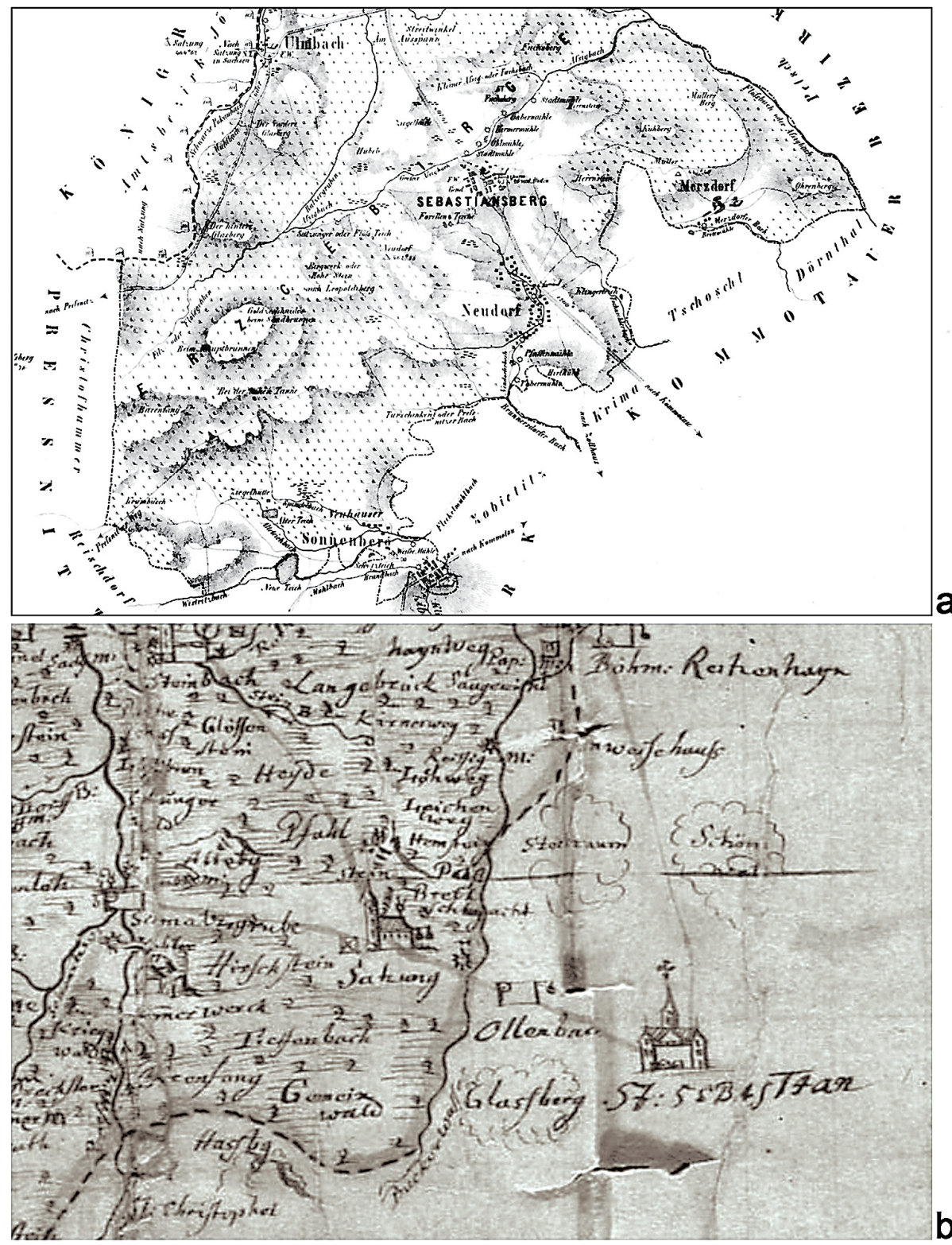

Obr. 2. Oronyma vypovídající o existenci skláren: a) výřez mapy F. Selnera z roku 1862 s vyznačením vrchů: Der Vordere Glasberg a Der hintere Glasberg (podle Selner ed., 1862); b) mapa A. F. Zürnera sasko-českého příhraničí z doby před r. 1742; vrch "Glasberg" východně od Hory sv. Šebestiána (Sächsisches Staatsarchiv, Hauptstaatsarchiv Dresden, 12884, Karten und Risse, Signatur/Inventar-Nr.: Makro 17850 \& (Schr 002, F 036, Nr 013) - www.deutschefotothek.de/documents/obj/90012404/dd_hstad-mf_0017850_002

Fig. 2. Oronyms testifying to the existence of glassworks: a - section of F. Selner's map from 1862 indicating the hills: Der Vordere Glasberg and Der Hintere Glasberg (after Selner ed. 1862); b - A. F. Zürner's map of the Saxon-Bohemian borderland from before 1742; Mt. Glasberg east of St. Sebastian Mountain (Sächsisches Staatsarchiv, Hauptstaatsarchiv Dresden, 12884, Karten und Risse, Signatur/Inventar-Nr.: Makro 17850 \& (Schr 002, F 036, Nr 013). 

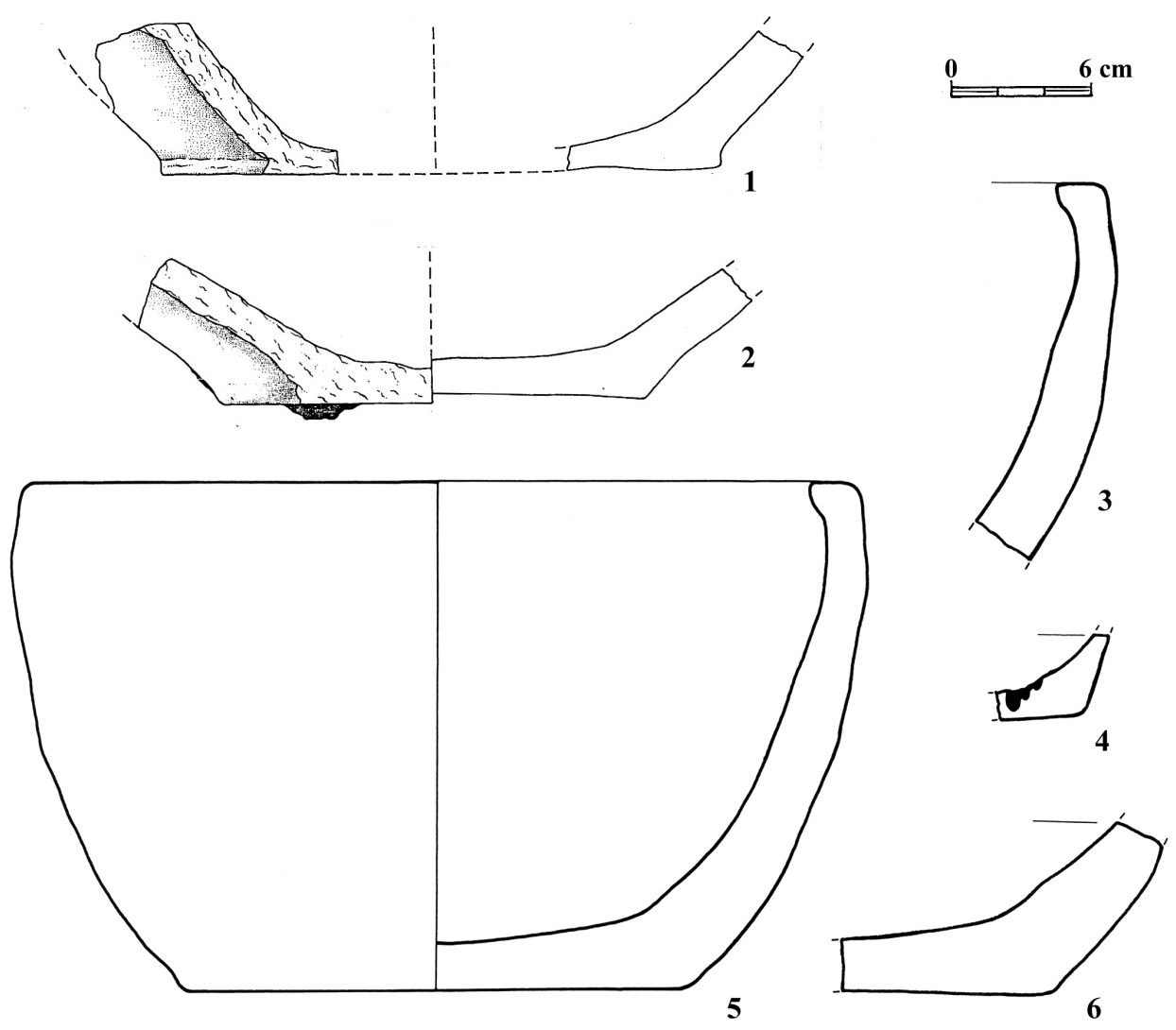

Obr. 3. Technická keramika. 1-2 - zlomky spodních partií sklářských pánví z naleziště jilmová III, 3-6 nálezy ze stanoviště Jilmová II (kresby na obr. 3, 6-7 H. Jonášová, J. Šílová).

Fig. 3. Technical ceramics. 1-2 - fragments of lower parts of melting pots from the Jilmová III site, 3-6 finds from the Jilmová II site.

\section{Předmět, metody a cíl výzkumu}

Podstatnou část nálezových souborů získaných povrchovými průzkumy a výzkumy středověkých skláren tvoří specifické předměty bezpečně indikující místa s výrobou skla. Patří k nim velké mísovité pánve (obr. 3), menší zkušební pánvičky (obr. 4), hlavně však nejrůznější formy sklářského odpadu, např. drobné kapičky, slitky a amorfní kousky skelného materiálu a ztuhlých tavenin, na které je v této práci zaměřena hlavní pozornost. Vzhledem k absenci výrobků, což je jev, se kterým se lze běžně setkat u soudobých skláren v horských oblastech nejen v Čechách, ale i jinde v Evropě (Stephan 1988/89), jsou dosavadní znalosti o domácí produkci stále mezerovité. Je obecně známo, že tehdejší sklárny ve střední Evropě používaly při tavení draselné alkálie získávané převážně z popela listnatých stromů (buků, popř. jiných vnitrozemských rostlin). Výsledná skla tudíž patřila do skupiny draselných skel. A přestože o jejich př́slušnosti k základnímu chemickému typu není pochyb, nebývá snadné zjistit přesné složení finálního surového skla. 

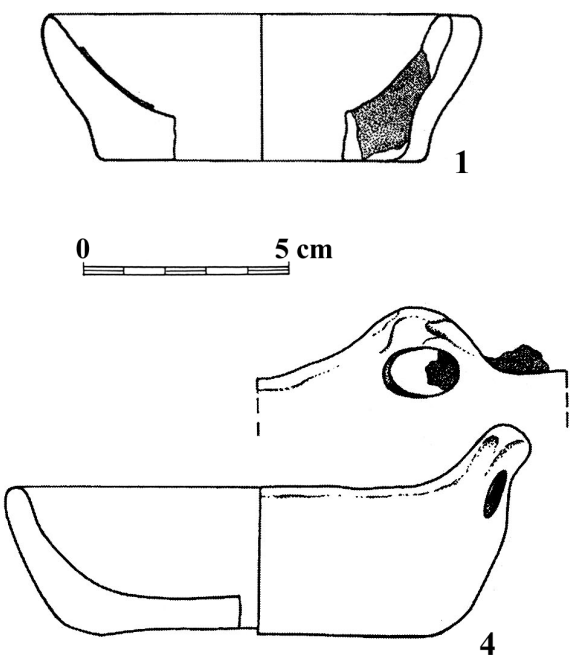

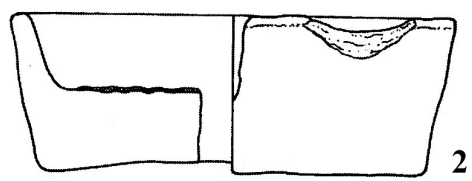

2
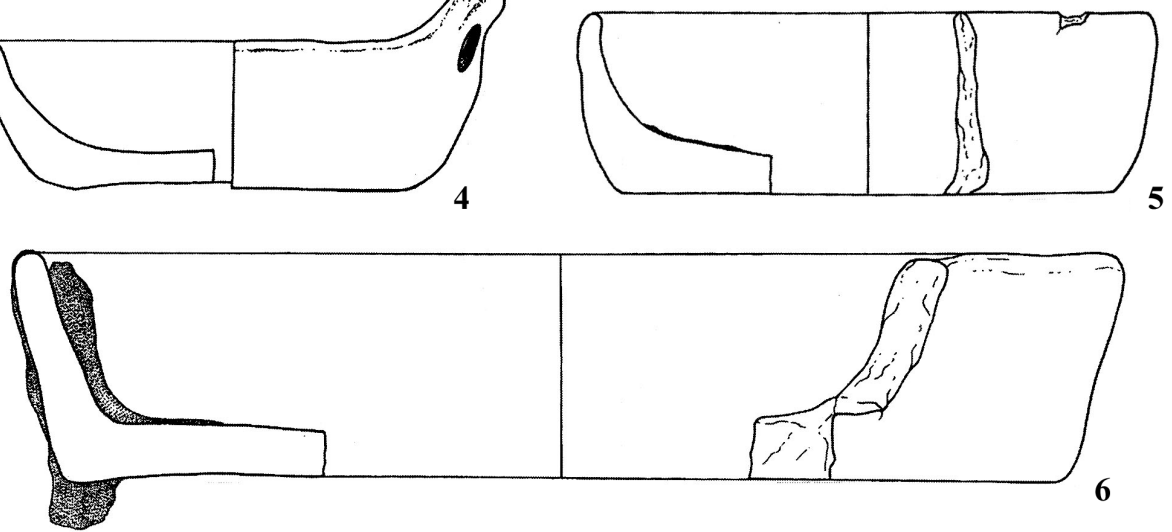

Obr. 4. Zlomky pánviček ze sklárny Jilmová I, II a III. 1 - miniaturní pánvička, kónické stěny s oblým okrajem, uvnitř, zbytky barevného skla. rozm.: dno $8 \mathrm{~cm}$, ústí $11 \mathrm{~cm}, v 3,7 \mathrm{~cm}$. Jilmová I (č. anal. 124); 2 - malá masivní pánvička, stěny přímé téměř svislé. Rozm.: dno 9,4cm, ústí 11 cm, v 3,7cm. Jilmová III (př. č. 60/88, č. anal. 2); 3 - pánvička s ouškem, mírně vyklenuté oblé stěny, uvnitř zbytky skla, rozm.: dno 8,4 cm, ústí 12,6 cm, v 3,6 cm. Jilmová II, (č. anal. 48); 4 - pánvička, stěny mírně vyklenuté s oblým okrajem, uvnitř slabá vrstva skla. Rozm.: dno 12,4cm, ústí 14,2 cm, v 4,6 cm. Jilmová II (č. anal. 50); 5 - větší pánvička, stěny přímé, mírně rozevřené, uvnitř i vně zbytky skla. Rozm.: dno $24,8 \mathrm{~cm}$, ústí $27,6 \mathrm{~cm}, \mathrm{v} 5,6 \mathrm{~cm}$. Jilmová II (č. anal. 53).

Fig. 4. Fragments of crucibles from the Jilmová I, II and III glassworks. 1 - conical sides with rounded rim, with residues of coloured glass inside. Dimensions: bottom $8 \mathrm{~cm}$, mouth $11 \mathrm{~cm}$, height $3.7 \mathrm{~cm}$. Jilmová I (analysis no. 124); 2 - massive, straight sides (nearly vertical). Dimensions: bottom $9.4 \mathrm{~cm}$, mouth $11 \mathrm{~cm}$, height $3.7 \mathrm{~cm}$. Jilmová III (acc. no. 60/88, analysis no. 2); 3 -crucible with handle, slightly convex rounded sides, residues of glass inside. Dimensions: bottom $8.4 \mathrm{~cm}$, mouth $12.6 \mathrm{~cm}$, height $3.6 \mathrm{~cm}$. Jilmová II (analysis no. 48); 4 - crucible, slightly convex sides with rounded rim, thin layer of glass inside. Dimensions: bottom $12.4 \mathrm{~cm}$, mouth $14.2 \mathrm{~cm}$, height $4.6 \mathrm{~cm}$. Jilmová II (analysis no. 50); 5 - crucible, straight sides, slightly everted, residues of glass inside and outside. Dimensions: bottom $24.8 \mathrm{~cm}$, mouth $27.6 \mathrm{~cm}$, height $5.6 \mathrm{~cm}$. Jilmová II (analysis no. 53).

Názorným dokladem tohoto jevu na území Čech je nálezová situace ve sklárnách jilmovského výrobního okruhu. Zpracování a vyhodnocení tamějších nálezů negativně ovlivňují dva faktory: nerovnoměrný rozsah výzkumu jednotlivých stanovišs' a omezená výpovědní hodnota nálezů daná samotnou podstatou archeologických pramenů. Pro získání dalších údajů jsou při hodnocení nálezů používány již od 80 . let 20. století nejrůznější analytické metody prírodovědných oborů. Nejprve byly aplikovány př̀i klasifikaci technické keramiky používané v hutní fázi výroby skla. Záměrem bylo zjistit fyzikální i che- 
mické vlastnosti žárovzdorných pánví a definovat kvalitu těchto sklářských pomůcek (Brabenec - Černá 1991). Později, po r. 2000, s rozvojem archeometrického výzkumu, byla věnována zvýšená pozornost též odpadním materiálům z hutní fáze výroby skla. V průběhu dvou let byly z nálezových souborů jilmovských skláren vybrány a metodami rentgenové fluorescenční analýzy (XRF), rentgenové difrakční analýzy (XRD) a skenovací elektronovou mikroskopií (SEM-EDS) postupně prozkoumány dvě nestejně početné kolekce vzorků odpadních skel a technické keramiky (Cílová - Hulínský 2004; Cílová 2008).

Vzhledem k závažnosti tématu výroby draselných skel vrcholného středověku je jejich chemickému složení dodnes věnována soustavná pozornost. V roce 2016 byla prozkoumána další série vzorků ze sklárny Jilmová I. ${ }^{3}$ Tato zahrnovala pouze 10 položek. S výjimkou jednoho vzorku (č. 1531), který svým nálezovým kontextem i doprovodnou keramikou nepochybně souvisí s pozdějšími aktivitami v tamější krajině, pravděpodobně montánního charakteru v 16. - počátku 17. století, devět zbývajících (č. 1532-1540) bylo vytipováno mezi nálezy sklářského odpadu. Na rozdíl od dříve analyzovaných vzorků byly tyto odebrány z amorfních kousků, které by podle vizuálně zjištěných morfologických znaků mohly pocházet ne z hutní, ale až následné zpracovatelské fáze výroby skla. Jako u předchozích měření byla použita metoda SEM-EDS a nově, pro stanovení prvků obsažených ve stopovém množství, byla aplikována metoda laserové ablace s hmotnostní spektrometrií indukčně vázaného plazmatu (LA-ICP-MS). ${ }^{4}$

Posun v poznání chemického složení skel tavených ve sklárnách u Jilmové přinesl rok 2019. Tehdy byla proměřena metodou LA-ICP-MS série vzorků analyzovaných již v předchozích letech 2002 a 2003 (tehdy SEM-EDS). ${ }^{5}$ Nová měření byla realizována se záměrem doplnit, resp. zpřesnit dř́vější poznatky o složení skel z jednotlivých stanovišt' a spolehlivěji definovat jejich příslušnost k základnímu chemickému typu. Současně se od nich očekávalo, že umožní, s přihlédnutím k nálezovému kontextu vzorků, osvětlit interpretaci odkrytých výrobních objektů na sklárně Jilmová I, zpřesnit poznatky o podobě středověkých skláren v českém Krušnohoří, a tím současně podpořit hypotézu o organizaci výroby skla na počátku vrcholného středověku, tzn. o existenci skláren různého typu.

\section{Nálezové okolnosti a charakteristika analyzovaných pramenů}

\section{Sklárna Jilmová I}

Poloha zaniklé sklárny byla identifikována v r. 1985 systematickou kontrolou odtěžených lesních ploch na severozápadních svazích dnešního Skelného vrchu. V témže roce byla realizována geofyzikální prospekce v místech, kde byly předchozími povrchovými sběry zaregistrovány zlomky užitkové keramiky spolu s nálezy specifickými pro sklářská

\footnotetext{
3 Výzkumný úkol GA ČR č. 14-5396S; analýzy byly provedeny Š. Jonášovou (2016) v laboratořích Geologického ústavu AV ČR.

4 Měření bylo provedeno v laboratořích MU Brno T. Vaculovičem.

5 Prehistorické a historické sklo z České republiky. Kontinuita dialogu archeologie a archeometrie, GA ČR č. 19-23566S.
} 


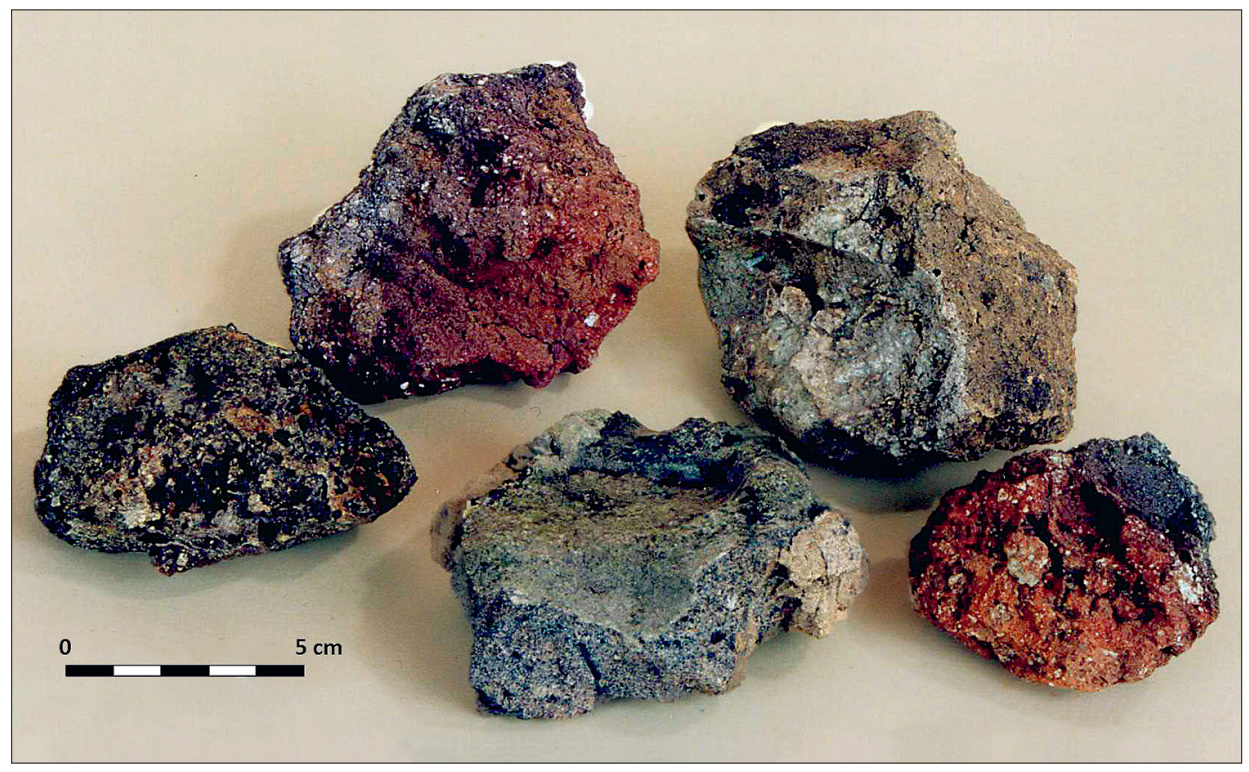

Obr. 5. Jilmová I. Spečené kusy vyzdívky stěn sklářských pecí (foto H. Sedláček).

Fig. 5. Jilmová I. Pieces of fused lining of glassmaking furnaces.

výrobní centra (Levý a kol. 1987; Čepela 1989). Na jedné ze tř́i zkoumaných ploch, na ploše A situované jižně od prameniště bezejmenného přítoku Hraničního potoka, kde se nalézalo nejvíce archeologických nálezů, včetně kusů vyzdívek (obr. 5), bylo naměřeno nejvíce výrazných magnetických anomálií signalizujících přítomnost pyrotechnologických zařízení. Do těchto míst směřoval pozdější archeologický výzkum. Proběhl ve třech krátkodobých etapách v 1. 1986-1988 formou plošných odkryvů. Potvrdilo se, že tři z nejvýraznějších naměřených anomálií, tzn. odchylek od normálního magnetického pole, ukrývají relikty výrobních objektů - sklářských pecí (Černá 2016, obr. 38). Všechny měly nepravidelný kruhový půdorys a byly zbudovány z lomového kamene a žáruvzdorných jílů. Vzhledem k tomu, že intaktně se dochovaly pouze nejnižší partie pláště pecí (do výšky 30-40 cm), včetně stěn topného kanálu umístěného zpravidla v podélné ose (naposledy Černá 2016, obr. 39-41), původní vzhled pecí lze rekonstruovat jen s větší či menší dávkou pravděpodobnosti. Z nalezených objektů byl největší obj. č. 6 (rozm.: 300 x 340 cm), jehož stěny se dochovaly do výšky $30 \mathrm{~cm}$. Ani menší pece nebyly stejně velké. Kromě toho, že se lišily svými rozměry (rozměry obj. č. 1: 250 x 210 x 40 cm a obj. č. 5: 210 x 210 x 30 cm), různily se též konstrukčními detaily (Černá 1995). Z výše uvedených údajů i dalších terénních zjištění se dalo soudit na rozdílnou funkci pecí. Největší z nich (obj. č. 6) sloužila k tavení skla. K čemu sloužily v rámci výrobního procesu menší pece (č. 1 a 5), to prozatím přesně nevíme. Nicméně na základě nevelkých odchylek v rozměrech a půdorysné dispozici bylo možné odvodit, že byly používány k rozdílným účelům, např. k přípravě frity, sušení dřeva, temperování pánví nebo dalších výrobků ze žáruvzdorných materiálů. Jsou tedy považovány za pece pomocné, aniž bychom je mohli pro torzovitost dochování přesněji interpretovat. Nabízí se otázka, zda a jak by mohla archeometrie přispět ke zpřesnění jejich funkce. 


\begin{tabular}{|l|r|r|r|r|r|}
\hline \multicolumn{1}{|c|}{ Jilmová I } & $\mathbf{1 9 8 6}$ & $\mathbf{1 9 8 7}$ & $\mathbf{1 9 8 8}$ & $\mathbf{1 9 8 9}$ & celkem \\
\hline keramika & 73 & 1156 & 592 & 22 & 1843 \\
\hline keramika glazovaná & 2 & 331 & 231 & & 564 \\
\hline kamenina & 1 & 21 & 12 & & 34 \\
\hline pánve & 156 & 276 & 63 & 44 & 539 \\
\hline pánvičky & 0 & 6 & 0 & & 849 \\
\hline sklo & 39 & 532 & 271 & 7 & 1 \\
\hline forma & 1 & & & & 25 \\
\hline vyzdívka & 25 & & & & 3861 \\
\hline celkem & 297 & 2322 & 1169 & 73 & \\
\hline
\end{tabular}

Tab. 1. Jilmová I. Kvantita a kvalita nálezových souborů z archeologických výzkumů v letech 1986-1989. Tab. 1. Jilmová I, Chomutov district. Quantity and quality of find assemblages from archaeological excavations in 1986-1989.

Jednotlivé etapy terénního výzkumu přinesly ve svém souhrnu velmi početný a různorodý nálezový soubor. Relativně velké procento v něm tvoří zlomky běžné užitkové keramiky, která umožňuje datovat sklárnu do 2. poloviny 13. století (obr. 6). Dále obsahuje zlomky technické keramiky, pánví i malých pánviček (obr. 4: 1), amorfní kusy opakní skelné hmoty z počáteční fáze tavení (frity, popř. ztuhlé taveniny) a také amorfní slitky nebo hrudky čirého surového skla. Celkový počet nálezů se pohybuje v řádu tisíců (tab. 1).

Nálezy byly nerovnoměrně rozptýlené po celé ploše výzkumu. Z distribuce jednotlivých druhů nálezů vyplynulo, že v blízkém okolí pecí převažovaly nálezy související s hutněním skla, tzn. nejrůznější formy výrobního odpadu, včetně ztuhlých zbytků tavenin nalézaných bud' volně, nebo na stěnách pánví i pánviček. Z celkového počtu nálezů bylo vybráno 127 vzorků a provedeno 131 analýz (tab. 2).

Při výběru vzorků pro archeometrický výzkum byly upřednostňovány nálezy bud' z destrukcí jednotlivých pecí, nebo z jejich těsné blízkosti a z výše zmíněných kategorií byla věnována zvýšená pozornost nálezům souvisejícím s hutněním skla (tab. 3).

V analyzovaném souboru vzorků jsou zastoupeny: pánve a pánvičky (19), vyzdívka (3), keramický články z pláště pece (1) a v neposlední řadě opakní hrudky ztuhlé taveniny nebo slitky čirého skla (104). Nejvíce vzorků pochází z destruovaného zdiva největšího objektu č. 6 - předpokládané tavicí pece (59) a 10 dalších vzorků je z plochy v jeho blízkém okolí. Zhruba o polovinu méně vzorků bylo vybráno z nálezů v kamenné destrukci menšího objektu č. 1 - tzv. pomocné pece (27), přičemž dalších 17 je z její blízkosti. Z nejmenšího objektu č. 5 - tzn. druhé pomocné pece je k dispozici pouze 10 vzorků. Rozdílný počet vzorků odráží v podstatě nálezovou situaci, resp. nerovnoměrnou distribuci nálezů. Zatímco okolí tavicí pece (obj. č. 6) jich poskytlo maximum, u oné menší pomocné pece se nacházely jen sporadicky. Jak již bylo výše řečeno, šlo o objekty, které, jak se domníváme na základě nestejných velikostí i dalších terénních zjištění, plnily v rámci výrobního procesu rozdílnou funkci. Teoreticky by tedy mezi vzorky skel i žárovzdorných materiálů z jednotlivých objektů mohly existovat rozdíly. V případě správnosti předpokladu by se tak naskytla možnost využít analýz k podložení dosavadních spekulativních názorů a v optimálním případě rovněž ke zpřesnění interpretace zvláště oněch dvou menších pomocných pecí. 


\begin{tabular}{|c|c|c|c|c|c|}
\hline Poř. č. & Vitrea & přír. č. & plocha, sektor & objekt, vrstva & druh nálezu \\
\hline 1 & & $93 / 86-5$ & $\mathrm{~A} /$ sek. II/5 & obj. 5, v. pod drnem & slitek čirý zelený \\
\hline 2 & & $93 / 86-7$ & A/sek. I/6 & obj. 6, v. pod drnem & slitek čirý zelenožlutý \\
\hline 3 & & $93 / 86-7$ & A/sek. I/6 & obj. 6, v. pod drnem & slitek čirý modrozelený \\
\hline 4 & & $93 / 86-7$ & A/sek. I/6 & obj. 6, v. pod drnem & spečenina šedohnědá opakní \\
\hline 5 & & $93 / 86-7$ & A/sek. I/6 & obj. 6, v. pod drnem & zlomek z rozhraní dna pánve \\
\hline 6 & & $93 / 86-7$ & A/sek. I/6 & obj. 6 , v. pod drnem & sklo zelené uvnitř vz. 60 \\
\hline 7 & & $93 / 86-7$ & A/sek. I/6 & obj. 6 , v. pod drnem & sklo modrozelené vně stěn vz. 60 \\
\hline 8 & 1995 & $93 / 86-11$ & $\mathrm{~A} /$ sek. II/5 & obj. 5, v. pod drnem & zlomek z rozhraní dna pánve \\
\hline 9 & & 93/86-11 & A/sek. II/5 & obj. 5, v. pod drnem & sklo modročerné uvnitř vz. 63 \\
\hline 10 & & $93 / 86-11$ & A/sek. II/5 & obj. 5 , v. pod drnem & sklo zelené vně vz. 63 \\
\hline 11 & & $93 / 86-12 a$ & A/sek. II/6 & obj. 6, v. pod drnem & fragment stěn pece \\
\hline 12 & & $93 / 86-12 a$ & A/sek. II/6 & obj. 6, v. pod drnem & sklo zelené z povrchu vz. 66 \\
\hline 13 & & $93 / 86-12 a$ & A/sek. II/6 & obj. 6, v. pod drnem & zlomek uzávěru okénka, jíl hnědožlutý \\
\hline 14 & & $93 / 86-12 a$ & A/sek. II/6 & obj. 6 , v. pod drnem & sklo zelené z povrchu vz. 68 \\
\hline 15 & 1996 & $93 / 86-14$ & A/sek. II/6 & obj. 6, nad destrukcí & amorfní slitek zelený \\
\hline 16 & & 93/86-14 & A/sek. II/6 & obj. 6, nad destrukcí & zrno křemene na bázi vz. 70 \\
\hline 17 & & 93/86-15 & A/sek. II/5-4 & obj. 5, mezi destrukcí & zlomek dna pánve, jíl světlešedý \\
\hline 18 & & $93 / 86-15$ & A/sek. II/5-4 & obj. 5, mezi destrukcí & sklo černé uvnitř vz. 72 \\
\hline 19 & & 93/86-15 & A/sek. II/5-4 & obj. 5, mezi destrukcí & sklo žlutozelené vně vz. 72 \\
\hline 20 & & $93 / 86-4$ & A/sek. I/6 & obj. 6, stěny kanálu pod tavicí komorou & spečenina opakní \\
\hline 21 & & $93 / 86-4$ & A/sek. I/6 & obj. 6, stěny kanálu pod tavicí komorou & křemen ze vz. 75 \\
\hline 22 & & $93 / 86-4$ & A/sek. I/6 & obj. 6, stěny kanálu pod tavicí komorou & sklo modré ze vz. 75 \\
\hline 23 & & $93 / 86-10$ & A/sek. II/4 & obj. 5, v. pod drnem & zlomek dna pánve, jíl světle šedý \\
\hline 24 & & $93 / 86-10$ & A/sek. II/4 & obj. 5, v. pod drnem & sklo černé uvnitř vz. 78 \\
\hline 25 & & $93 / 86-10$ & A/sek. II/4 & obj. 5, v. pod drnem & sklo čiré vně vz. 78 \\
\hline 26 & & 93/86-13 & A/sek. I/6 & obj. 6, v. nad podložím & zlomek dna pánve, jíl světle šedý \\
\hline 27 & 1997 & 93/86-13 & A/sek. I/6 & obj. 6, v. nad podložím & sklo modročerné uvnitř vz. 81 \\
\hline 28 & & 93/86-13 & A/sek. I/6, & obj. 6, v. nad podložím & sklo žlutobílé vně vz. 81 \\
\hline 29 & & $37 / 87-14$ & A/sek. I/6 & obj. 6, povrch destrukce & zlomek okraje pánve, jíl světle šedý \\
\hline 30 & & $37 / 87-14$ & A/sek. I/6 & obj. 6, povrch destrukce & sklo zelené uvnitř vz. 84 \\
\hline 31 & & $37 / 87-14$ & A/sek. I/6 & obj. 6, povrch destrukce & sklo zelené vně vz. 84 \\
\hline 32 & & $37 / 87-14$ & A/sek. I/6 & obj. 6, povrch destrukce & zlomek dna pánve, jíl světle šedý \\
\hline 33 & & $37 / 87-14$ & A/sek. I/6 & obj. 6, povrch destrukce & skl. kmen uvnitř vz. 87 (?) \\
\hline 34 & 1998 & $37 / 87-18$ & A/sek. I/7 & v. u obj. 6 & slitek amorfní zelený \\
\hline 35 & & $37 / 87-18$ & A/sek. I/7 & v. u obj. 6 & amorfní slitek zelenomodrý \\
\hline 36 & & $37 / 87-18$ & A/sek. I/7 & v. u obj. 6 & Žlutobílá vyzdívka na vz. 90 \\
\hline 37 & & $37 / 87-18$ & A/sek. I/7 & v. u obj. 6 & zlomek pánve, jíl tmavě šedý \\
\hline 38 & & $37 / 87-18$ & A/sek. I/7 & v. u obj. 6 & sklo uvnitř vz. 92 \\
\hline 39 & & $37 / 87-18$ & A/sek. I/7 & v. u obj. 6 & sklo zelené vně vz. 92 \\
\hline 40 & & $37 / 87-33$ & A/sek. I/6 & vně obvodu obj. 1 & zlomek dna pánve, jíl světle šedý \\
\hline 41 & 1999 & $37 / 87-33$ & A/sek. I/6 & vně obvodu obj. 1 & sklo modré uvnitř vz. 95 \\
\hline 42 & & $37 / 87-33$ & A/sek. I/6 & vně obvodu obj. 1 & sklo zelené vně vz. 95 \\
\hline 43 & & $37 / 87-40$ & A/sek. I & destrukce obj. 1 & zlomek dna pánve, jíl světle šedý \\
\hline 44 & & $37 / 87-40$ & A/sek. I & destrukce obj. 1 & sklo hnědočerné uvnitř vz. 98 \\
\hline 45 & & $37 / 87-40$ & A/sek. I & destrukce obj. 1 & sklo světle žluté vně vz. 98 \\
\hline 46 & & $37 / 87-42$ & A/sek. I/7 & obj. 1, SZ obvod destrukce & zlomek rozhraní dna pánvičky, jíl světle šedý \\
\hline 47 & 2002 & $37 / 87-42$ & A/sek. I/7 & obj. 1, SZ obvod destrukce & sklo zelené uvnitř̌ vz. 101 \\
\hline 48 & & $37 / 87-42$ & A/sek. I/7 & obj. 1, SZ obvod destrukce & sklo červené uvnitř vz. 101 \\
\hline 49 & & $37 / 87-42$ & A/sek. I/7 & obj. 1, SZ obvod destrukce & sklo namodralé vně vz. 101 \\
\hline 50 & & $37 / 87-42$ & A/sek. I/7 & obj. 1, SZ obvod destrukce & zlomek rozhraní dna pánve, jíl světle šedý \\
\hline 51 & 2000,2001 & $37 / 87-42$ & A/sek. I/7 & obj. 1, SZ obvod destrukce & sklo fialové až černé uvnitř vz. 105 \\
\hline 52 & & $37 / 87-42$ & A/sek. I/7 & obj. 1, SZ obvod destrukce & sklo zelené (?) vně vz. 105 \\
\hline 53 & & $37 / 87-36$ & A/sek. I/7 & u obj. 1, v. nad podložím & zlomek dna pánve, jíl světle šedý \\
\hline 54 & 2003 & $37 / 87-36$ & A/sek. I/7 & u obj. 1, v. nad podložím & sklo zelené uvnitř vz. 108 \\
\hline 55 & & $37 / 87-36$ & A/sek. I/7 & u obj. 1, v. nad podložím & sklo zelené vně vz. 108 \\
\hline 56 & & $37 / 87-48$ & A/sek. III/6 & u obj. 1, v. nad podložím & zlomek dna pánve, jíl světle šedý \\
\hline 57 & & $37 / 87-48$ & A/sek. III/6 & u obj. 1, v. nad podložím & sklo modročerné uvnitř vz. 111 \\
\hline 58 & & $37 / 87-44$ & A/sek. III/5 & u obj. 1, v. nad podložím & zlomek okraje pánvičky, jíl světle šedý \\
\hline 59 & & $37 / 87-44$ & A/sek. III/5 & u obj. 1, v. nad podložím & sklo zelené uvnitř vz. 113 \\
\hline 60 & & $37 / 87-54$ & A/sek. II/6 & obj. 6, V polovina destrukce & zlomek pánve, jíl světle šedý \\
\hline 61 & & $37 / 87-54$ & A/sek. II/6 & obj. 6, V polovina destrukce & sklo zelené uvnitř vz. 115 \\
\hline 62 & & $37 / 87-54$ & A/sek. II/6 & obj. 6, V polovina destrukce & vyzdívka na vz. 115 \\
\hline 63 & & $37 / 87-66$ & A/sek. II/6 & obj. 6, střed destrukce & zlomek pánvičky, jíl žlutošedý \\
\hline 64 & 2004 & $37 / 87-66$ & A/sek. II/6 & obj. 6, střed destrukce & sklo modročerné uvnitř vz. 118 \\
\hline 65 & & $37 / 87-66$ & A/sek. II/6 & obj. 6, střed destrukce & sklo tmavomodré vně vz. 118 \\
\hline 66 & & $37 / 87-68$ & A/sek. II/6 & obj. 6, povrch zdiva & zlomek pánve, jíl světle šedý \\
\hline 67 & & $37 / 87-68$ & A/sek. II/6 & obj. 6, povrch zdiva & sklo zelené vně vz. 121 \\
\hline
\end{tabular}




\begin{tabular}{|c|c|c|c|c|c|}
\hline 68 & & $37 / 87-72$ & A/sek. II/6 & obj. 1, u ústí kanálu & frita hnědočerná \\
\hline 69 & & $37 / 87-70$ & A/sek. III & obj. 1, výplň kanálu & zlomek pánvičky, jíl světle šedý \\
\hline 70 & & $37 / 87-70$ & A/sek. III & obj. 1, výplň kanálu & sklo světle žluté uvnitř vz. 124 \\
\hline 71 & 2005 & $58 / 88-1$ & A/sek. II/6 & obj. 6, mezi destrukcí & slitek světle zelený \\
\hline 72 & 2006 & $58 / 88-1$ & A/sek. II/6 & obj. 6, mezi destrukcí & slitek čirý světle zelený \\
\hline 73 & & $58 / 88-1$ & A/sek. II/6 & obj. 6, mezi destrukcí & nečistoty na vz. 127 \\
\hline 74 & 2007 & $58 / 88-26$ & A/sek. II/6 & obj. 6, výpň kanálu & slitek zelenomodrý \\
\hline 75 & 2008 & $58 / 88-26$ & A/sek. II/6 & obj. 6, výpň kanálu & slitek žlutý \\
\hline 76 & & $58 / 88-26$ & A/sek. II/6 & obj. 6, výpň kanálu & slitek zelený \\
\hline 77 & & $58 / 88-26$ & A/sek. II/6 & obj. 6, výpň kanálu & amorfní kousek zeleného skla \\
\hline 78 & & $58 / 88-26$ & $\mathrm{~A} /$ sek. II/6 & obj. 6, výpň kanálu & slitek zelenožlutý \\
\hline 79 & 2009 & $58 / 88-26$ & A/sek. II/6 & obj. 6, výpň kanálu & slitek nezjistitelné barvy \\
\hline 80 & & $58 / 88-26$ & A/sek. II/6 & obj. 6, výpň kanálu & amorfní kousek struskovité hmoty šedohnědé \\
\hline 81 & & $58 / 88-6$ & A/sek. II/6 & obj. 6, Z obvod zdiva & slitek světlezelený \\
\hline 82 & & $58 / 88-6$ & A/sek. II/6 & obj. 6, Z obvod zdiva & slitek nezjistitelné barvy \\
\hline 83 & 2010 & $58 / 88-6$ & A/sek. II/6 & obj. $6, Z$ obvod zdiva & slitek zelenomodrý \\
\hline 84 & 2011 & $58 / 88-6$ & A/sek. II/6 & obj. 6, Z obvod zdiva & slitek světle žlutý \\
\hline 85 & & $58 / 88-6$ & A/sek. II/6 & obj. 6, Z obvod zdiva & slitek světle zelená \\
\hline 86 & 2012 & $58 / 88-6$ & A/sek. II/6 & obj. 6, Z obvod zdiva & slitek tmavě zelený \\
\hline 87 & & $58 / 88-6$ & A/sek. II/6 & obj. 6, Z obvod zdiva & slitek zelený \\
\hline 88 & & $58 / 88-18$ & A/sek. II/6 & obj. 6, S odvod zdiva & slitek zelený \\
\hline 89 & 2013 & $37 / 87-58$ & A/sek. II/7 & u obj. 6 , v. nad podložím & slitek světle zelený \\
\hline 90 & & $37 / 87-57$ & A/sek. I/7 & u obj. 6, v. nad podložím & slitek zelenožlutý \\
\hline 91 & 2014 & $37 / 87-62$ & A/sek. III & obj. 1, kontrol. blok & slitek zelený \\
\hline 92 & & $37 / 87-31$ & A/sek. III/7 & u obj. 1, v. humózní hnědá & slitek zelený \\
\hline 93 & 2015 & $37 / 87-31$ & A/sek. III/7 & u obj. 1, v. humózní hnědá & slitek zelený \\
\hline 94 & & $37 / 87-31$ & A/sek. III/7 & u obj. 1, v. humózní hnědá & slitek světle zelený \\
\hline 95 & & $37 / 87-33$ & A/sek. III/6 & obj. 1, J obvod zdiva & slitek světle zelený \\
\hline 96 & 2016 & $37 / 87-33$ & A/sek. III/6 & obj. 1, J obvod zdiva & slitek světle zelený \\
\hline 97 & 2017 & $37 / 87-32$ & A/sek. II/6 & obj. 6, v. tmvě hnědá & slitek světle zelený \\
\hline 98 & & $37 / 87-32$ & A/sek. II/6 & obj. 6, v. tmvě hnědá & slitek světle zelený \\
\hline 99 & & $37 / 87-32$ & A/sek. II/6 & obj. 6, v. tm. hnědá & slitek světle zelený \\
\hline 100 & 2018 & $37 / 87-32$ & A/sek. II/6 & obj. 6, v. tm. hnědá & kousek skla se zbytky nečistot \\
\hline 101 & 2019 & $37 / 87-13$ & A/sek. II/6 & obj. 6, povrch destrukce & slitek světle zelený \\
\hline 102 & & $37 / 87-13$ & A/sek. II/6 & obj. 6, povrch destrukce & sklo na vyzdívce \\
\hline 103 & & $37 / 87-25$ & A/sek. III/7 & obj. 1, povrch podloží u S části & slitek tmavozelený \\
\hline 104 & 2020 & $37 / 87-25$ & A/sek. III/7 & obj. 1, povrch podloží u S části & slitek zelenožlutý \\
\hline 105 & 2021 & $37 / 87-26$ & A/sek. III/6 & obj. 1, povrch destrukce & slitek světle zelený \\
\hline 106 & 2022 & $37 / 87-26$ & A/sek. III/6 & obj. 1, povrch destrukce & slitek světle zelený \\
\hline 107 & & $37 / 87-29$ & A/sek. II/7 & u obj. 6, v. žlutohnědá nad podložím & slitek čirý světle zelený \\
\hline 108 & & $37 / 87-28$ & A/sek. I/6 & u obj. 6, v. žlutohnědá nad podložím & slitek čirý žlutý \\
\hline 109 & & $37 / 87-67$ & A/sek. III & obj. 1, výplň kanálu & slitek čirý zelený \\
\hline 110 & & $37 / 87-70$ & A/sek. III & obj. 1, výplň kanálu & slitek čirý žlutozelený \\
\hline 111 & 2023 & $37 / 87-70$ & A/sek. III/7 & obj. 1, výplň kanálu & slitek čirý světle zelený \\
\hline 112 & & $37 / 87-41$ & A/sek. II/7 & u obj. 6, v. hnědá nad podložím & slitek čirý světle zelený \\
\hline 113 & & $37 / 87-41$ & A/sek. II/7 & u obj. $6, v$. hnědá nad podložím & slitek čirý zelený \\
\hline 114 & 2024 & $37 / 87-44$ & A/sek. 1/5 & u obj. 6, v. hnědá nad podložím & slitek čirý světle zelený \\
\hline 115 & & $37 / 87-43$ & A/sek. III/5 & u obj. 1, v. hnědá nad podložím & slitek čirý tmavě zelený \\
\hline 116 & 2025 & $37 / 87-43$ & A/sek. III/5 & u obj. 1, v. hnědá nad podložím & slitek čirý zelenožlutý \\
\hline 117 & & $37 / 87-40$ & A/sek. III/6 & obj. 1, mezi destrukcí & slitek čirý světle zelený \\
\hline 118 & & $58 / 88-8$ & $\mathrm{~B} / \mathrm{s} 2 / 87-\mathrm{B}$ & v. černošedá uhlíkatá & okenní destička světle zelená \\
\hline 119 & & $37 / 87-63$ & $\mathrm{~B} / \mathrm{s} 2 / 87-\mathrm{B}$ & v. hnědá nad podložím & okenní destička světle zelená \\
\hline 120 & & $37 / 87-63$ & $\mathrm{~B} / \mathrm{s} 2 / 87-\mathrm{B}$ & v. hnědá nad podložím & okenní destička zelenožlutá \\
\hline 121 & & $37 / 87-63$ & $B / s 2 / 87-B$ & v. hnědá nad podložím & okenní destička zelenožlutá \\
\hline 122 & 1531 & $37 / 87-63$ & $\mathrm{~B} / \mathrm{s} 2 / 87-\mathrm{B}$ & v. hnědá nad podložím & okenní destička našedlá \\
\hline 123 & 1532 & $37 / 87-50$ & A/sek. II/6 & obj. 6, kamenná destrukce & amorfní vlákno čiré zelené \\
\hline 124 & 1533 & $37 / 87-31$ & A/sek. III/7 & obj. 1, v. humózní hnědá & amorfní vlákno čiré zelenožluté \\
\hline 125 & 1534 & $37 / 87-35$ & A/sek. I/6 & u obj. 1, v. hnědá nad podložím & amorfní vlákno čiré zelené \\
\hline 126 & 1535 & $37 / 87-13$ & A/sek. II/6 & obj. 6 , povrch destrukce & amorfní vlákno čiré zelenožluté \\
\hline 127 & 1536 & $37 / 87-23$ & A/sek. II/III/7 & obj. 1, v. pod drnem & amorfní vlákno čiré zelené \\
\hline 128 & 1537 & $37 / 87-25$ & A/ sek. 1/7 & obj. 1, povrch podloží & amorfní vlákno čiré zelenožluté \\
\hline 129 & 1538 & $37 / 87-29$ & A/sek. II/7 & u obj. 6, v. žlutohnědá nad podložím & amorfní vlákno čiré zelenožluté \\
\hline 130 & 1539 & $37 / 87-70$ & A/sek. III & obj. 1, výplň kanálu & amorfní vlákno čiré zelenožluté \\
\hline 131 & 1540 & $37 / 87-41$ & A/sek. II/7 & u obj. 6 , v. hnědá nad podložím & amorfní vlákno zelenožluté \\
\hline
\end{tabular}

Tab. 2. Jilmová I, okr. Chomutov. Soupis analyzovaných vzorků v letech 2002, 2003 a 2016.

Tab. 2. Jilmová I, Chomutov district. List of samples analysed in 2002, 2003 and 2016. 

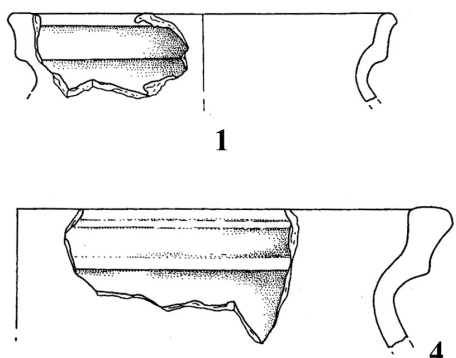

4
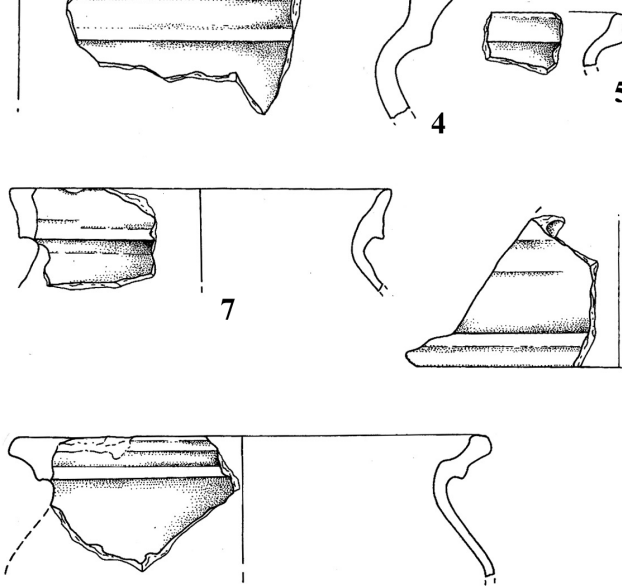

10

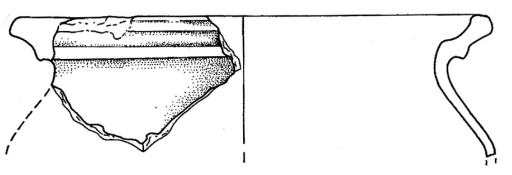

5

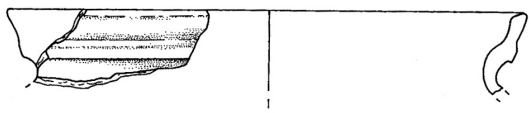

6

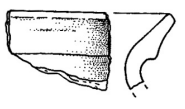

2

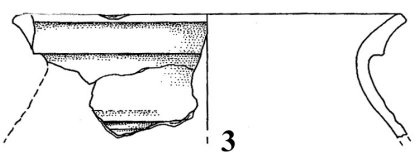

6

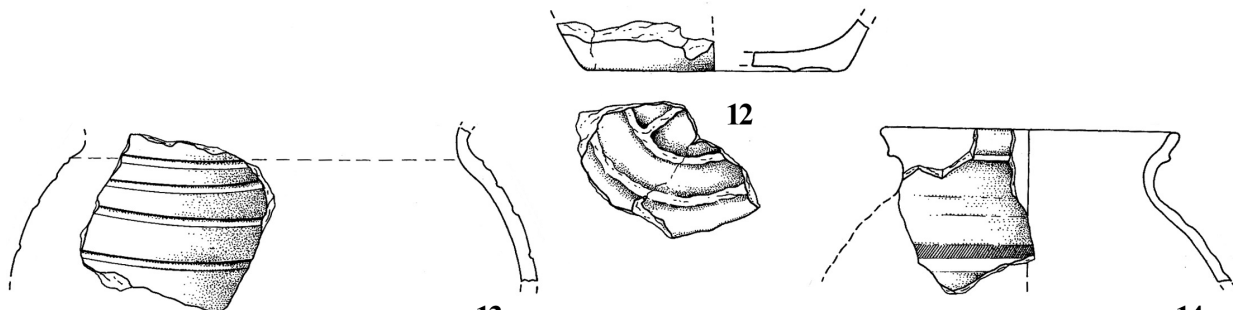

13

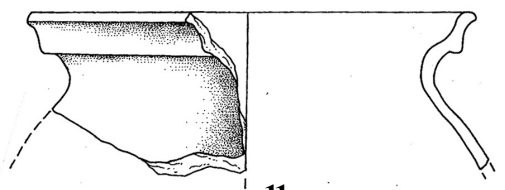

11

14
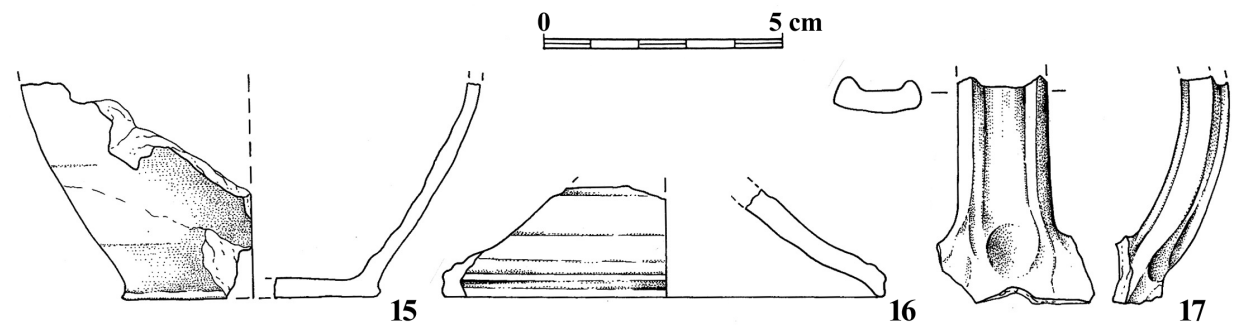

Obr. 6. Sklárna Jilmová I. Výběr nálezů užitkové keramiky.

Fig. 6. Jilmová I glassworks. Selection of finds of utility ceramics.

\section{Jilmová II}

Byla objevena v r. 1987 na mírném k SSZ přivráceném svahu, v blízkosti prameniště a zaniklé úvozové cesty probíhající východně od naleziště směrem od jihozápadu na severovýchod. Od sklárny Jilmová I je vzdálena pouze ca 800 m vzdušnou čarou směrem na SSV. Při detailním povrchovém průzkumu a následném geodeticko-topografickém 


\begin{tabular}{|l|c|c|c|c|c|}
\hline \multicolumn{1}{|c|}{ Kontext } & pánve a pánvičky & vyzdívka & ker. články & sklo & celkem \\
\hline obj. 6 & 7 & 2 & 1 & 49 & 59 \\
\hline okolí obj. 6 & 1 & 1 & & 8 & 10 \\
\hline obj. 5 & 3 & & & 7 & 10 \\
\hline obj. 1 & 5 & & & 14 & 27 \\
\hline okolí obj. 1 & 3 & & & 4 & 17 \\
\hline B/s2/87 & & & $\mathbf{1}$ & $\mathbf{1 0 4}$ & $\mathbf{1 2 7}$ \\
\hline celkem & $\mathbf{1 9}$ & $\mathbf{3}$ & & & 4 \\
\hline
\end{tabular}

Tab. 3. Jilmová I, okr. Chomutov. Nálezový kontext analyzovaných vzorků s uvedením četnosti jednotlivých druhů.

Tab. 3. Jilmová I, Chomutov district. Find context of analysed samples with the frequency of individual types.

výzkumu realizovaném v témže roce bylo registrováno v silně narušeném povrchu sedm objektů, a to na základě vegetačních příznaků, terénního reliéfu i rozptylu nálezů (Černá 1989; 2016, obr. 51). V témže roce proběhl geofyzikální výzkum. Magnetometrické měření na ploše 30 x 30 m zachytilo 10 anomálií lišících se navzájem výší odchylek i velikostí plochy, které se jen zčásti překrývaly s objekty vytipovanými při předchozím povrchovém průzkumu ve vegetačním pokryvu. Z naměřených hodnot (z velikosti odchylek i jejich plošného rozsahu) je zřejmé, že většina z nich indikuje bud' relikty pyrotechnologických objektů in situ nebo místa s rozvlečeným materiálem z různých částí jejich stěn (srov. Černá 2016, obr. 52).

Prozatím byla provedena pouze nevelká zjištovací sonda $\mathrm{v}$ místech dvou naměřených anomálií. V ní byly zachyceny relikty nevelké oválné pece, jež umožnila lokalitu bezpečně interpretovat jako středověkou sklárnu. Pro malý rozsah výzkumu však nebylo možno jednoznačně určit, jakého byla typu. Terénní zjištění spolu se skladbou nálezového souboru nás vedou k domněnce, že zde stávala sklárna tzv. mateřská, na které se sklo nejen tavilo, ale též zpracovávalo. Prozatím však zde nebyly nalezeny zlomky hotových výrobků, které by mohly tuto domněnku podepřít.

Z povrchových průzkumů i zjištovacího archeologického výzkumu byl získán soubor čítající 365 zlomků nálezů různého druhu. Z celkového počtu tvořila naprostou většinu (277) užitková keramika (obr. 7), zatímco nálezů specifických pro sklářskou výrobu bylo nepoměrně méně (tab. 4;obr. 3: 3-6).

\begin{tabular}{|l|c|c|c|}
\hline \multicolumn{1}{|c|}{ Jilmová II } & $\mathbf{1 9 8 7}$ & $\mathbf{1 9 8 8}$ & celkem \\
\hline keramika & 93 & 184 & 277 \\
\hline pánve & 29 & 15 & 44 \\
\hline pánvičky & 8 & 3 & 11 \\
\hline keramické články & & 7 & 26 \\
\hline sklo & desítky & 26 & 0 \\
\hline forma & 0 & 0 & 0 \\
\hline vyzdívka & 0 & 0 & 365 \\
\hline celkem & 123 & 235 & \\
\hline
\end{tabular}

Tab. 4. Jilmová II, okr. Chomutov. Kvantita a kvalita nálezového souboru.

Tab. 4. Jilmová II, Chomutov district. Quantity and quality of find assemblages. 


\begin{tabular}{|c|c|c|c|c|c|}
\hline Poř. č. & Vitrea & přír. č. & $\begin{array}{l}\text { objekt, } \\
\text { plocha }\end{array}$ & vrstva & druh nálezu \\
\hline 1 & & $59 / 88-32$ & obj. 2 & povrch destrukce & zlomek stěny pánve, jíl světle šedý \\
\hline 2 & & $59 / 88-32$ & obj. 2 & povrch destrukce & zlomek stěny pánve s okrajem, jíl světle šedý \\
\hline 3 & & $59 / 88-32$ & obj. 2 & povrch destrukce & sklo zelené vně vz. 15 \\
\hline 4 & & $59 / 88-42$ & okolí obj. 3 & v. $10-16 \mathrm{~cm}$ & zlomek dna pánve se sklem, jíl světle žlutý \\
\hline 5 & & $59 / 88-42$ & okolí obj. 3 & v. $10-16 \mathrm{~cm}$ & zlomek dna pánvičky, jíl světle žlutý \\
\hline 6 & 1992 & $59 / 88-42$ & okolí obj. 3 & v. $10-16 \mathrm{~cm}$ & zlomek dna pánvičky s fritou (?), jíl světle šedý \\
\hline 7 & & $59 / 88-42$ & okolí obj. 3 & v. $10-16 \mathrm{~cm}$ & amorfní hrudka hnědočerné frity \\
\hline 8 & & $59 / 88-42$ & okolí obj. 3 & v. $10-16 \mathrm{~cm}$ & zlomek okraje pánve, jíl světle šedý \\
\hline 9 & & $59 / 88-42$ & okolí obj. 3 & v. $10-16 \mathrm{~cm}$ & sklo šedozelené uvnitř vz. 21 \\
\hline 10 & & $59 / 88-42$ & okolí obj. 3 & v. $10-16 \mathrm{~cm}$ & zlomek stěny pánve, jíl nažloutlý \\
\hline 11 & & $59 / 88-42$ & okolí obj. 3 & v. $10-16 \mathrm{~cm}$ & sklo silně zkorodované hnědošedé vně vz. 23 \\
\hline 12 & & $59 / 88-42$ & okolí obj. 3 & v. $10-16 \mathrm{~cm}$ & zlomek spodní části pánve, jíl světle žlutý \\
\hline 13 & & $59 / 88-42$ & okolí obj. 3 & v. $10-16 \mathrm{~cm}$ & tavenina hnědočerná vně vz. 25 \\
\hline 14 & & $59 / 88-42$ & okolí obj. 3 & v. $10-16 \mathrm{~cm}$ & zlomek okraje pánvičky s ouškem, jíl světle šedý \\
\hline 15 & & $59 / 88-42$ & okolí obj. 3 & v. $10-16 \mathrm{~cm}$ & sklo nazelenalé uvnitř vz. 27 \\
\hline 16 & & $59 / 88-45$ & mezi obj. 3-2 & v. $10-16 \mathrm{~cm}$ & spodní část pánve, jíl světle šedý \\
\hline 17 & & $59 / 88-45$ & mezi obj. 3-2 & v. $10-16 \mathrm{~cm}$ & sklo modré z vnějšího povrchu vz. 29 \\
\hline 18 & & $59 / 88-45$ & mezi obj. 3-2 & v. $10-16 \mathrm{~cm}$ & slitek zploštělý zelenofialový \\
\hline 19 & & $59 / 88-45$ & mezi obj. 3-2 & v. $10-16 \mathrm{~cm}$ & amorfní hrudka zeleného skla \\
\hline 20 & & $59 / 88-45$ & mezi obj. 3-2 & v. $10-16 \mathrm{~cm}$ & vyzdívka se sklem vz. 32 \\
\hline 21 & & $59 / 88-28$ & obj. 3 & vnitřní komora & zlomek dna a stěn pánvičky, jíl světle šedý \\
\hline 22 & & $59 / 88-28$ & obj. 3 & vnitřní komora & sklo zelené uvnitř vz. 34 \\
\hline 23 & & $59 / 88-28$ & obj. 3 & vnitřní komora & sklo zelené z vnějšího povrchu vz. 34 \\
\hline 24 & & $59 / 88-28$ & obj. 3 & vnitřní komora & zlomek okraje pánve, jíl světle šedý \\
\hline 25 & & $59 / 88-28$ & obj. 3 & vnitřní komora & sklo hnědožluté uvnitř vz. 37 \\
\hline 26 & & $59 / 88-28$ & obj. 3 & vnitřní komora & sklo nazelenalé vně vz. 37 \\
\hline 27 & & $59 / 88-16$ & plocha & poddrní & amorfní kousek vyzdívky, hmota světle šedá \\
\hline 28 & & $59 / 88-16$ & plocha & poddrní & rozhraní dna a stěn pánve, jíl světle šedý \\
\hline 29 & & $59 / 88-16$ & plocha & poddrní & sklo šedočerné vně vz. 41 \\
\hline 30 & & $59 / 88-16$ & plocha & poddrní & zlomek okraje pánve, jíl světle šedý \\
\hline 31 & & $59 / 88-16$ & plocha & poddrní & sklo žlutohnědé vně vz. 43 (?) \\
\hline 32 & & $38 / 87-5$ & obj. 3 & povrch & zlomek stěny pánve, jíl světle šedý \\
\hline 33 & & $38 / 87-5$ & obj. 3 & povrch & sklo žlutohnědé uvnitř vz. 45 \\
\hline 34 & 1993 & $38 / 87-8$ & obj. 5 & povrch & vápenec \\
\hline 35 & & $38 / 87-11$ & obj. 7 & povrch & torzo pánvičky s ouškem, jíl světle šedý \\
\hline 36 & & $38 / 87-11$ & obj. 7 & povrch & nedotavené sklo šedožluté unitř vz. 48 \\
\hline 37 & & $38 / 87-11$ & obj. 7 & povrch & torzo pánvičky, jíl světle šedý \\
\hline 38 & & $38 / 87-11$ & obj. 7 & povrch & sklo červené uvnitř vz. 50 \\
\hline 39 & & $38 / 87-11$ & obj. 7 & povrch & sklo žlutobílé vně vz. 50 \\
\hline 40 & 1994 & $38 / 87-11$ & obj. 7 & povrch & torzo pánvičky tmavošedé \\
\hline 41 & & $38 / 87-11$ & obj. 7 & povrch & nedotavené sklo šedočerné uvnitř vz. 53 \\
\hline 42 & & $38 / 87-11$ & obj. 7 & povrch & nedotavené sklo šedočerné vně vz. 53 \\
\hline
\end{tabular}

Tab. 5. Soupis vzorků ze sklárny Jilmová II analyzovaných v roce 2002.

Tab. 5. Jilmová II, Chomutov district. List of samples analysed in 2002. 


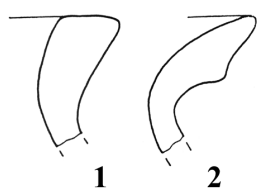

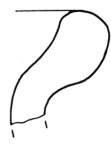

3

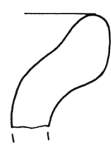

4
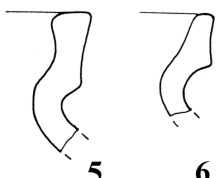

6

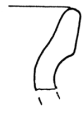

7
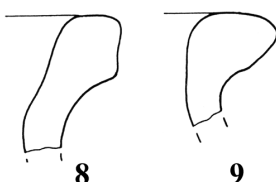

9

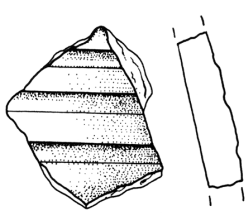

10

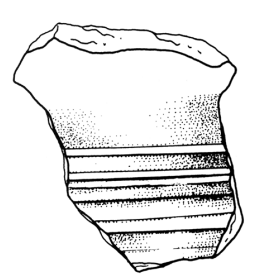

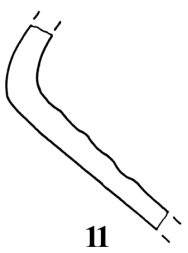
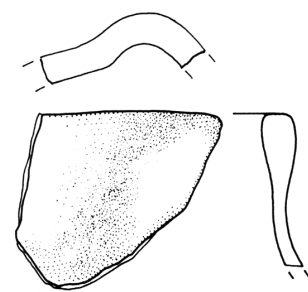

12

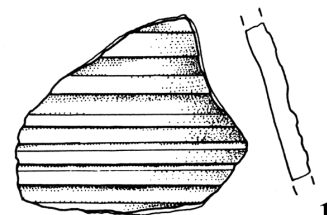

13

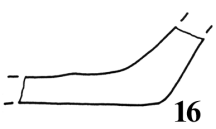

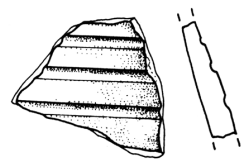

14

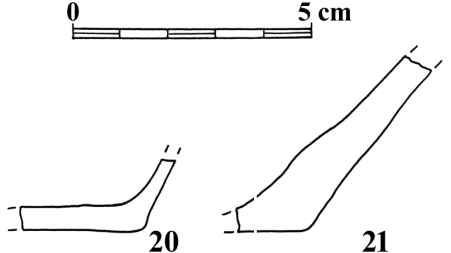

Obr. 7. Sklárna Jilmová II. Výběr nálezů užitkové keramiky.

Fig. 7. Jilmová II glassworks. Selection of finds of utility ceramics.

S ohledem na nižší celkový počet nálezů v porovnání s lokalitou Jilmová I bylo analyzováno méně vzorků, pouze 42 kusů (tab. 5). Tyto pocházejí, obdobně jako v předchozím případě, především z okolí výrobních objektů ( $t a b .6)$. Časově omezený rámec zjišt’ovacího výzkumu nedovolil prozkoumat relikty pecí v úplnosti, takže získaná archeologická data nebyla relevantní ani pro stanovení jejich primární funkce, ani typu zdejší sklárny.

\begin{tabular}{|l|c|c|c|c|c|}
\hline \multicolumn{1}{|c|}{ Kontext } & pánve a pánvičky & vyzdívka & ker. články & sklo & celkem \\
\hline obj. 2 & 2 & & & 1 & 3 \\
\hline obj. 3 & 3 & & & 5 & 8 \\
\hline okolí obj. 3 & 6 & & & 6 & 12 \\
\hline mezi obj. 2 a 3 & 1 & 1 & & 3 & 5 \\
\hline plocha & 2 & 1 & & 2 & 5 \\
\hline obj. 5 & & & 1 & & 1 \\
\hline obj. 7 & 3 & & & 5 & 8 \\
\hline celkem & $\mathbf{1 7}$ & $\mathbf{2}$ & $\mathbf{1}$ & $\mathbf{2 2}$ & $\mathbf{4 2}$ \\
\hline
\end{tabular}

Tab. 6. Jilmová II, okr. Chomutov. Nálezový kontext analyzovaných vzorků s uvedením četnosti jednotlivých druhů.

Tab. 6. Jilmová II, Chomutov district. Find context of analysed samples with the frequency of individual types. 


\begin{tabular}{|l|c|c|c|}
\hline \multicolumn{1}{|c|}{ Jilmová III } & $\mathbf{1 9 8 8}$ & $\mathbf{2 0 0 3}$ & celkem \\
\hline keramika & 25 & 35 & 60 \\
\hline pánve & 25 & 11 & 36 \\
\hline pánvičky & 1 & 2 & 3 \\
\hline vyzdívka & 3 & & 3 \\
\hline sklo & 4 & 1 & 5 \\
\hline železo & & 14 & 14 \\
\hline olovo & & 2 & 2 \\
\hline celkem & 58 & 65 & 123 \\
\hline
\end{tabular}

Tab. 7. Jilmová III, okr. Chomutov. Kvantita a kvalita nálezového souboru.

Tab. 7. Jilmová III, Chomutov district. Quantity and quality of find assemblages.

\begin{tabular}{|c|l|c|c|c|l|}
\hline Poř. č. & Vitrea & č. anal. & přír. č. & kontext & \multicolumn{1}{c|}{ druh nálezu } \\
\hline 1 & & 1 & $60 / 88-38$ & povrch skrývky & kulička zeleného skla \\
\hline 2 & & 2 & $60 / 88-39$ & povrch skrývky & torzo pánvičky, světlešedá \\
\hline 3 & & 3 & $60 / 88-39$ & povrch skrývky & zelené sklo uvnitř vz. 2 \\
\hline 4 & & 4 & $60 / 88-39$ & povrch skrývky & zl. dna pánve, světlešedá \\
\hline 5 & & 5 & $60 / 88-39$ & povrch skrývky & zl. stěny pánve, světlešedá \\
\hline 6 & & 6 & $60 / 88-39$ & povrch skrývky & zl. stěny pánve, světlešedá \\
\hline 7 & & 7 & $60 / 88-39$ & povrch skrývky & sklo zelené, uvnitř vz. 6 \\
\hline 8 & & 8 & $60 / 88-39$ & povrch skrývky & zl. stěny pánve, světlešedá \\
\hline 9 & & 9 & $60 / 88-39$ & povrch skrývky & sklo/tavenina černá, uvnitř vz. 8 \\
\hline 10 & & 10 & $60 / 88-39$ & povrch skrývky & zl. spodní části pánve, šedá \\
\hline 11 & & 11 & $60 / 88-39 b$ & povrch skrývky & zelené sklo na vz. 12 \\
\hline 12 & & 12 & $60 / 88-39 b$ & povrch skrývky & amorfní kus černé vyzdívky \\
\hline 13 & 1991 & 13 & $60 / 88-39 b$ & povrch skrývky & amorfní kus hnědočerné frity (?) \\
\hline
\end{tabular}

Tab. 8. Soupis analyzovaných vzorků ze sklárny Jilmová III.

Tab. 8. Jilmová III, Chomutov district. List of samples.

\section{Jilmová III}

Sklárna se nachází na temeni dnešního Skelného vrchu, v blízkosti bezejmenné a v současnosti zaniklé drobné vodoteče (viz Černá 2016, obr. 56). Byla objevena v roce 1988 v místech určených pro novou lesní výsadbu, kde byly povrchové hlinité vrstvy odbagrovány až na mateční horninu. $\mathrm{V}$ porovnání $\mathrm{s}$ ostatními lokalitami byla nejvíce poškozena, resp. totálně zničena. Prvotní kontrolou skrytých ploch bylo objeveno jen několik artefaktů souvisejících s výrobou skla (zlomky pánví a skleněné kapičky). Opakované povrchové průzkumy přinesly další analogické nálezy, na jejichž základě bylo možno lokalizovat do těchto míst středověkou sklárnu. Nacházela se zhruba v polovině spojnice lokalit Jilmová I a II, vzdálena od prvně jmenované asi 300 m. Geofyzikální výzkum prokázal, že při úpravách povrchu došlo k úplnému zničení výrobních objektů, resp. k přesunutí reliktů pecí z původních míst spolu s nadložními vrstvami do hlinitých valů oddělujících jednotlivé plochy pro novou výsadbu. Existenci sklárny v těchto místech znovu prokázal záchranný výzkum realizovaný v roce 2003 v souvislosti s výstavbou nové trasy Telecomu na Chomutovsku, mezi Horou sv. Šebestiána a Kryštofovými Hamry. Na stěnách liniového 

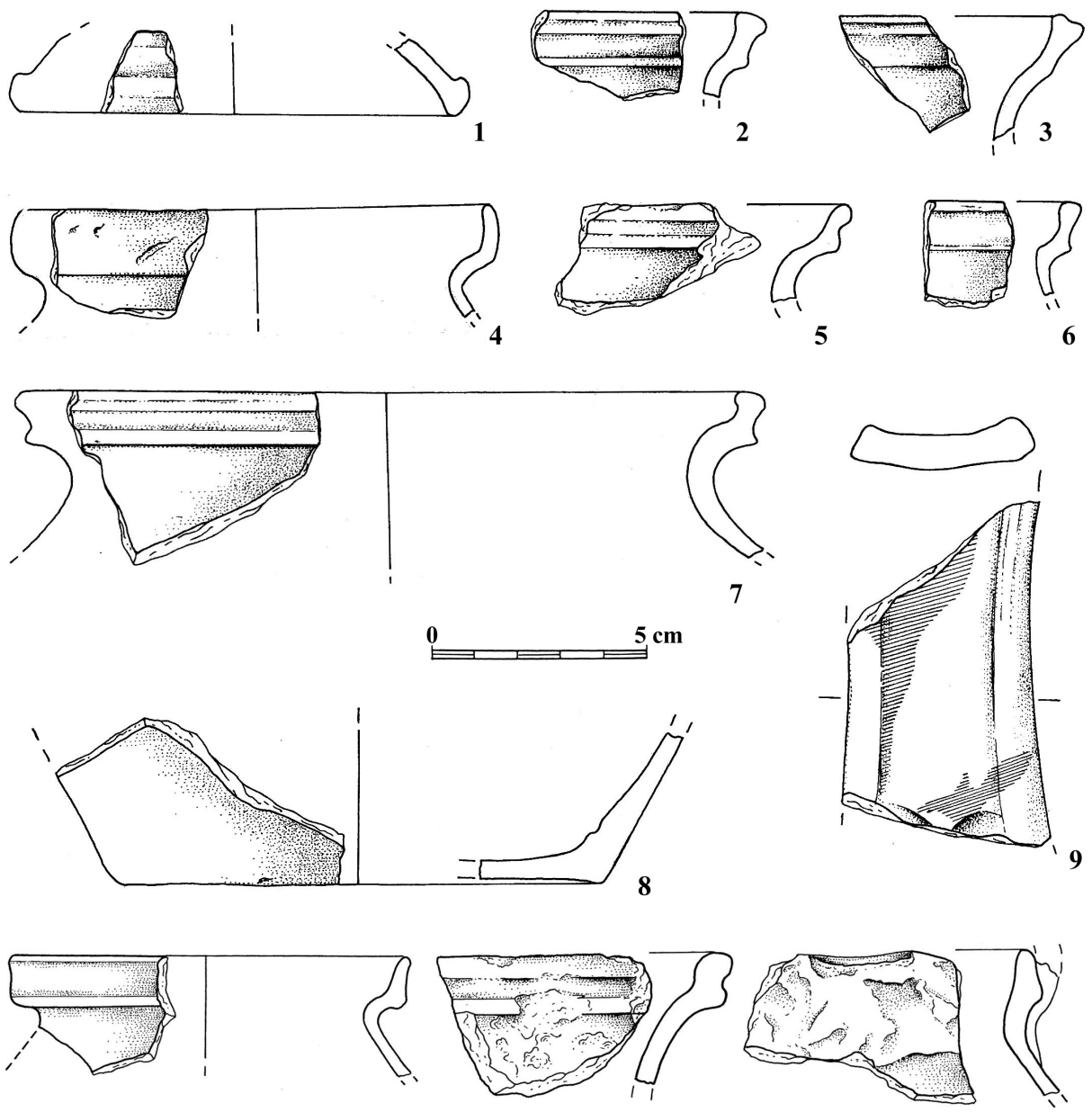

10

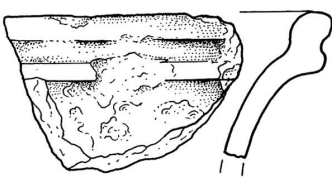

11
12

Obr. 8. Sklárna Jilmová III. Výběr nálezů užitkové keramiky.

Fig. 8. Jilmová III glassworks. Selection of finds of utility ceramics.

výkopu, který probíhal podél východní strany stávající silnice, bylo zjištěno a zdokumentováno v délce zhruba 76 m nízké souvrství obsahující kromě užitkové keramiky předměty specifické pro sklářská centra výroby (Černá 2016, 88-90). Nálezový soubor získaný dosavadními terénními akcemi čítá 123 položek (tab. 7).

Zhruba polovinu z tohoto počtu tvoří zlomky užitkové keramiky ( $o b r$. 8), zbytek tvoří nálezy indikující výrobu skla, konkrétně zlomky pánví (obr. 3: 1, 2), pánviček (obr. 4: 2), kusy nedotaveného opakního skla nebo kapičky z čirého nazelenalého, popř. nažloutlého skla. Součástí nálezového souboru je kolekce železných předmětů, které se podařilo dohledat $\mathrm{v}$ roce 2003 pomocí detektoru v místech, odkud byly získány povrchovými průzkumy nálezy již v 80. letech 20. století. Tato kolekce obsahuje jak artefakty sídlištního charakteru (hřeby, podkovy, kopí ad.), tak také zlomky sklářského nářadí (nože a kovové tyčinky př́lepníky?). Spolu s nimi byly nalezeny také dva velké kusy olova, které však s ohledem 
na místo i způsob získání, není možné jednoznačně spojit s někdejší výrobou skla. Na analýzy bylo vybráno pouze 13 vzorků ze starších kolekcí z 80. let (tab. 8). Tamější technická keramika (pánve a pánvičky) je reprezentována šesti ks, sklo v podobě malých čirých nazelenalých slitků rovněž šesti vzorky a výčet uzavírá amorfní kus vyzdívky.

\section{Analytická část}

\subsection{Soubor analyzovaných indikátorů sklářské výroby}

Hodnocení a interpretace indikátorů souvisejících s výrobou skla je předmětem řady prací (Mendera et al. 2005; Fenzi et al. 2013, 473-513). Některé indikátory, které se nacházejí v areálech skláren, mohou být poměrně snadno interpretovány bud' jako fragmenty výrobků, nebo pánví. Další skupinu tvoří nálezy, jejichž zařazení do konkrétní výrobní fáze bývá problematické (např. kusy homogenního i heterogenního skla, skelná vlákna či kapky). Lze si klást otázku, kde nebo při jaké činnosti vlastně vznikly. Je diskutabilní, zda se jedná o „vypichy“ (zkušební materiál, pomocí kterého sklář testoval kvalitu skloviny), či o „odstřiky“ vzniklé např. při manipulaci s pánví nebo kapky náhodně vzniklé při tavení skla v tavicí komoře pece. Komplikovaná je rovněž interpretace výsledků analýz chemického složení těchto vzorků. Otázkou je, zda naměřené hodnoty složení daného vzorku/indikátoru reprezentují finální typ skla, který se v lokalitě tavil.

V následujícím textu budou hodnoceny heterogenní kusy hmot nalezených v místech výrobních objektů, vrstvy skla ulpělé v tavících pánvích, pánve samotné a drobné skleněné nálezy jako kapky a jiné. Předložený text navazuje na starší práci (Cílová 2008), během níž bylo proměřeno: a) 13 vzorků porézních hmot obsahujících skelnou i krystalickou složku; XRF a XRD, b) 21 vzorků skel z vnitřního povrchu pánví metodou SEM-EDS, c) 59 vzorků kapek, vláken apod. stejnou metodou a d) 45 vzorků fragmentů pánviček a pánví metodou XRF a fázové složení metodou XRD (doplňkově bylo provedeno stanovení vlastností strepů).

Pro řešení problematiky technologie výroby skla byla rovněž použita metoda LAICP-MS (umožňující stanovení prvků ve stopovém množství). Sada vzorků (tab. 9) byla vybrána s ohledem na výsledky předchozích měření. V textu je tedy diskutován i př́nos metody LA-ICP-MS při řešení otázek týkajících se výroby skla a využitelnosti některých prvků k určení surovin. Text dále popisuje, jak lze s takto heterogenní skupinou vzorků a získanými daty pracovat, a na co lze z výsledků usuzovat.

\subsection{Př́prava vzorků a analytické metody}

Př́íprava vzorků pro analýzy byla volena s ohledem na jejich velikost a plánované měření. Pro metody XRF a XRD byly vzorky připraveny ve formě prášků. $V$ př́padě menších vzorků kapek $(\mathrm{ca} 1 \mathrm{~cm})$ byly vzorky v analyticky vhodném místě lehce broušeny a leštěny (méně destruktivní odběr). Při procesu leštění byl opticky kontrolován stav povrchu, aby se zjistilo, zda byla odstraněna korozní vrstva, popř. nečistoty vzniklé kontaminací povrchu nálezovým prostředím. Jedině tak bylo možné proměřit sklo nepoškozené v důsledku korozních procesů.

Naleštěné vzorky byly použity při měření metodami SEM-EDS a LA-ICP-MS. Byly měřeny na rastrovacím elektronovém mikroskopu Hitachi S-4700 vybaveném EDS analyzátorem NORAN D-6823 (ÚSK, VŠCHT Praha) při urychlovacím napětí $20 \mathrm{kV}$. Pro stanovení homogenity vzorků byla měření 
prováděna nejméně v pěti různých místech nábrusu po dobu 100 sekund při použitém zvětšení $500 \mathrm{x}$. Získaná spektra byla vyhodnocena a převedena na koncentrace pomocí bezstandardového korekčního programu ZAF.

Přesnost a správnost použitého korekčního programu a samotného měření byla průběžně ověřována pomocí analýzy vzorků o známém složení (standardu $)^{6}$. Shodný vzorek byl použit i př̌i měření metodou LA-ICP-MS.

Metoda XRF byla zvolena pro stanovení chemického složení heterogenních hmot a střepové hmoty tavicích pánví. Měření bylo provedeno na vlnově dispersním rentgenfluorescenčním spektrometru ARL 9400 XP v Centrálních laboratořích VŠCHT Praha. Pro vyhodnocení byl použit semikvantitativní vyhodnocovací program Uniquant. Pro identifikaci krystalických fází bylo provedeno měření na rentgenovém difraktometru X'PERT PRO firmy Philips při záření Cu Ka při 40 kV/30 mA.

Vybraná sada vzorků (36) byla analyzována i pomocí LA-ICP-MS v Ústavu chemie Přrírodovědecké fakulty Masarykovy univerzity. Instrumentace zahrnovala laserový ablační systém UP213 (NewWave) emitující laserové záření o vlnové délce 213 nm s délkou pulzu 4,2 ns. Laserem produkovaný aerosol byl z ablační komory odnášen proudem He (průtok 1,0 $1 \mathrm{~min}^{-1}$ ) do ICP-MS spektrometru Agilent 7500ce (Agilent) s kvadrupólovým analyzátorem a kolizně-reakční celou. Laserová ablace byla provedena za optimalizovaných podmínek (průměr ablačního kráteru $65 \mu \mathrm{m}$, opakovací frekvencí $10 \mathrm{~Hz}$ a hustotou zářivé energie $15 \mathrm{~J} \mathrm{~cm}^{-2}$ ) na pěti místech daného vzorku. Pro kvantifikaci výsledků byly použity referenční materiály NIST610 a Corning reference glass D; pro potlačení vlivu různé ablační rychlosti byla použita normalizace na sumu obsahu oxidů.

\section{Výsledky analýz}

\subsection{Porézní heterogenní vzorky}

Některé z analyzovaných vzorků byly velmi heterogenní kusy hmot. Metodou XRF bylo zjištěno, že lze tyto vzorky rozdělit na dvě skupiny s rozdílným obsahem $\mathrm{Al}_{2} \mathrm{O}_{3}$ a $\mathrm{CaO}$ (Cílová 2008). První skupina s poměrně vysokými hodnotami $\mathrm{Al}_{2} \mathrm{O}_{3}(\operatorname{nad} 8 \mathrm{hm} . \%$ ) a spíše nízkým obsahem alkálií (obsah $\mathrm{CaO}$ max. $7 \mathrm{hm} . \%$ ) představuje hmoty náhodně vzniklé při tavícím procesu a nelze je označit jako finální produkty výroby skla (převažující krystalickou fází byl křemen a leucit - $\mathrm{KAlSi}_{2} \mathrm{O}_{6}$ ). Fázi leucitu ve vzorcích meziproduktů výroby sice nelze zcela vyloučit, nicméně by měla být zastoupena v menším množství, a spíše jako doprovodná fáze hlavní složky - wollastonitu (např. Messiga et al. 2004). Druhou skupinu s nižším obsahem $\mathrm{Al}_{2} \mathrm{O}_{3}$ a vyšším obsahem alkálií reprezentuje vzorek č. 1991 (tab. 9; uvedena pouze analýza skelné fáze). U tohoto vzorku byla v krystalické části nalezena i výše diskutovaná fáze wollastonitu $\left(\mathrm{CaSiO}_{3}\right)$. Použití popela rostlin př̀i výrobě dokládá přítomnost fosforu. Vzorek současně obsahoval vyšší obsah $\mathrm{Fe}_{2} \mathrm{O}_{3}$, a nelze ho tak označit jako surovinu vhodnou pro další zpracování; neodpovídá konzistence produktu (jak bude řešeno dále $v$ textu).

Vzhledově obdobná nehomogenní hmota byla nalezena i na vnitřním povrchu některých pánví (obr. 9). Vzorky byly pro další měření připraveny ve formě nábrusu ( $o b r .10$ a 11$)$ a bylo zjištěno, že pod heterogenní opakní vrstvou hnědé barvy jsou relikty hmoty skelné povahy. Zatímco opakní horní vrstvy obsahují opět vysoké množství $\mathrm{Al}_{2} \mathrm{O}_{3}$ (přes $10 \%$ ) a pro středověké sklo nevyhovující množství alkálií (Cúlová 2008; Černá 2017), skelné vrstvy poskytují zajímavá data.

${ }^{6}$ Standard (typ D) pro měrení historických skel byl získán z muzea The Corning Museum of Glass, New York. 


\begin{tabular}{|c|c|c|c|c|c|c|c|c|c|c|c|}
\hline \begin{tabular}{|c|} 
Číslo \\
Vitrea \\
\end{tabular} & typ & $\begin{array}{c}\mathrm{Na}_{2} \mathrm{O} \\
(\%)\end{array}$ & $\begin{array}{c}\mathrm{MgO} \\
(\%)\end{array}$ & $\begin{array}{c}\mathrm{Al}_{2} \mathrm{O}_{3} \\
(\%)\end{array}$ & $\begin{array}{c}\mathrm{SiO}_{2} \\
(\%)\end{array}$ & $\begin{array}{c}\mathrm{P}_{2} \mathrm{O}_{5} \\
(\%)\end{array}$ & $\begin{array}{l}\mathrm{K}_{2} \mathrm{O} \\
(\%)\end{array}$ & $\begin{array}{l}\mathrm{CaO} \\
(\%)\end{array}$ & $\begin{array}{c}\mathrm{MnO} \\
(\%)\end{array}$ & $\begin{array}{c}\mathrm{Fe}_{2} \mathrm{O}_{3} \\
(\%)\end{array}$ & $\begin{array}{l}\mathrm{CuO} \\
(\%)\end{array}$ \\
\hline 1991 & heterogenní hmota & $<$ LoD & 1,06 & 1,13 & 62,03 & 0,80 & 11,28 & 5,88 & 0,19 & 18,42 & 0,00 \\
\hline 1992 & vrstva skla v pánvi & $<$ LoD & 1,60 & 3,38 & 41,67 & 1,06 & 11,58 & 11,49 & 0,52 & 9,54 & 0,31 \\
\hline 1994 & heterogenní vrstva skla v pánvi & $<$ LoD & 2,97 & 3,03 & 56,67 & 0,99 & 13,92 & 20,40 & 0,69 & 0,68 & 0,01 \\
\hline 1995 & vrstva skla v pánvi & $<$ LoD & 3,31 & 0,90 & 53,55 & 1,61 & 19,34 & 19,67 & 0,68 & 0,26 & 0,01 \\
\hline 1996 & skelná hmota & $<$ LoD & 0,81 & 3,28 & 76,27 & 0,18 & 13,33 & 4,36 & 0,19 & 1,08 & 0,01 \\
\hline 1997 & vrstva skla v pánvi & $<$ LoD & 3,64 & 1,61 & 51,47 & 1,58 & 17,57 & 22,03 & 0,90 & 0,38 & 0,01 \\
\hline 1998 & skelná hmota & $<$ LoD & 2,76 & 3,37 & 66,49 & 0,93 & 11,96 & 12,37 & 0,48 & 0,90 & 0,01 \\
\hline 1999 & vrstva skla v pánvi & $<$ LoD & 2,99 & 4,94 & 58,68 & 0,89 & 14,28 & 14,51 & 0,59 & 1,49 & 0,48 \\
\hline 2000 & vrstva skla v pánvi & $<$ LoD & 3,46 & 0,91 & 51,95 & 1,62 & 19,80 & 20,70 & 0,67 & 0,27 & 0,01 \\
\hline 2001 & vrstva skla v pánvi & $<$ LoD & 3,38 & 0,84 & 51,88 & 1,67 & 19,48 & 21,12 & 0,67 & 0,31 & 0,01 \\
\hline 2002 & vrstva skla v pánvi & $<$ LoD & 2,60 & 5,47 & 58,84 & 0,93 & 13,47 & 13,36 & 0,47 & 0,83 & 2,92 \\
\hline 2003 & vrstva skla v pánvi & $<$ LoD & 2,18 & 4,41 & 67,85 & 0,66 & 11,08 & 11,63 & 0,51 & 0,97 & 0,02 \\
\hline 2004 & vrstva skla v pánvi & $<$ LoD & 2,43 & 3,40 & 62,41 & 0,73 & 14,30 & 10,44 & 0,45 & 4,52 & 0,52 \\
\hline 2005 & skelná hmota & $<$ LoD & 0,70 & 4,30 & 77,49 & 0,16 & 12,03 & 3,16 & 0,17 & 1,41 & 0,01 \\
\hline 2006 & skelná hmota & $<$ LoD & 1,03 & 3,44 & 75,82 & 0,30 & 12,21 & 5,39 & 0,23 & 1,04 & 0,01 \\
\hline 2007 & skelná hmota & $<$ LoD & 2,52 & 3,05 & 62,82 & 0,76 & 14,44 & 13,97 & 0,56 & 1,13 & 0,02 \\
\hline 2008 & kapka & $<$ LoD & 2,79 & 3,91 & 64,63 & 1,15 & 14,45 & 10,36 & 0,57 & 1,33 & 0,02 \\
\hline 2009 & skelná hmota & $<$ LoD & 3,58 & 2,91 & 62,10 & 1,24 & 14,13 & 14,21 & 0,56 & 0,53 & 0,01 \\
\hline 2010 & kapka & $<$ LoD & 1,52 & 3,17 & 70,84 & 0,47 & 13,81 & 8,25 & 0,29 & 1,05 & 0,02 \\
\hline 2011 & kapka & $<$ LoD & 1,90 & 3,68 & 68,70 & 0,56 & 13,15 & 9,72 & 0,36 & 1,27 & 0,02 \\
\hline 2012 & kapka & $<$ LoD & 0,31 & 4,00 & 73,64 & 0,10 & 16,57 & 0,98 & 0,11 & 3,98 & 0,01 \\
\hline 2013 & skelná hmota & 3,34 & 1,14 & 3,01 & 77,29 & 0,35 & 7,93 & 5,49 & 0,22 & 0,72 & 0,01 \\
\hline 2014 & skelná hmota & $<$ LoD & 1,69 & 3,34 & 68,24 & 0,50 & 14,73 & 9,37 & 0,39 & 1,09 & 0,01 \\
\hline 2015 & skelná hmota & $<$ LoD & 1,79 & 3,22 & 67,21 & 0,63 & 14,81 & 10,06 & 0,44 & 1,16 & 0,01 \\
\hline 2016 & skelná hmota & $<$ LoD & 1,31 & 3,85 & 71,04 & 0,38 & 14,24 & 7,18 & 0,28 & 1,13 & 0,01 \\
\hline 2017 & kapka & $<$ LoD & 0,49 & 3,11 & 77,80 & 0,15 & 14,13 & 2,53 & 0,10 & 1,36 & 0,01 \\
\hline 2018 & skelná hmota & 2,09 & 1,05 & 3,23 & 76,05 & 0,27 & 10,41 & 4,82 & 0,23 & 1,38 & 0,01 \\
\hline 2019 & skelná hmota & $<$ LoD & 1,93 & 4,47 & 68,13 & 0,53 & 14,12 & 8,69 & 0,37 & 1,07 & 0,01 \\
\hline 2020 & skelná hmota & $<$ LoD & 2,83 & 3,12 & 63,91 & 0,89 & 13,78 & 13,10 & 0,59 & 1,08 & 0,02 \\
\hline 2021 & skelná hmota & $<$ LoD & 1,38 & 3,18 & 72,58 & 0,38 & 12,60 & 7,79 & 0,27 & 1,28 & 0,01 \\
\hline 2022 & skelná hmota & $<$ LoD & 1,26 & 3,22 & 69,76 & 0,39 & 15,44 & 7,58 & 0,28 & 1,48 & 0,01 \\
\hline 2023 & kapka & $<$ LoD & 1,39 & 3,93 & 71,42 & 0,33 & 13,26 & 7,63 & 0,27 & 1,21 & 0,01 \\
\hline 2024 & skelná hmota & 2,80 & 1,13 & 3,47 & 75,44 & 0,28 & 9,42 & 5,12 & 0,23 & 1,60 & 0,01 \\
\hline 2025 & kapka & $<$ LoD & 3,21 & 4,17 & 63,50 & 1,07 & 14,00 & 11,37 & 0,62 & 1,27 & 0,02 \\
\hline 2038 & heterogenní vrstva skla v pánvi & $<$ LoD & 2,07 & 2,19 & 56,26 & 0,72 & 10,55 & 26,8 & 0,49 & 0,59 & 0,01 \\
\hline 1531 & terčík & 2,30 & 3,91 & 2,47 & 57,30 & 2,87 & 4,54 & 24,53 & 0,84 & 0,60 & 0,01 \\
\hline
\end{tabular}

Tab. 9a. Chemické složení indikátorů sklářské výroby; LA-ICP-MS (obsahy v hm.\%). Čísla vzorků v tab. 9a-c odpovídají číslování v databázi chemických analýz pravěkých až novověkých skel Vitrea (https://digitalhumanities.cz/db/databaze-vitrea/). Zkratka < LoD - under limits of detection.

Tab. 9a. Chemical composition of glass production indicators; LA-ICP-MS (contents in wt\%). The sample numbers in tab. $9 a-c$ correspond to the numbering in the VITREA database of chemical analyses of prehistoric to modern glass (https://digitalhumanities.cz/db/databaze-vitrea/). < LoD - under limits of detection.

Vzorek (č. 1992: tab. 9) byl pro měření metodou LA-ICP-MS připraven ve formě nábrusu (obr. 11) a bylo zjištěno, že pod heterogenní/drolivou opakní vrstvou je relikt modrého skla obsahující i kovovou částici (obr. 11 a tab. 9, č. 2037). Obdobně byl připraven i vzorek č. 1994 (obr. 10). V tomto případě je vrstva skla nehomogenní a metodou optické polarizační mikroskopie i metodou XRD byla stanovena krystalická fáze - diopsid/ $\mathrm{MgCaSi}_{2} \mathrm{O}_{6}$. Oba vzorky poukazují na draselno-vápenaté sklo, obsah $\mathrm{Al}_{2} \mathrm{O}_{3}$ je vyšší 


\begin{tabular}{|c|c|c|c|c|c|c|c|c|c|c|c|c|c|}
\hline $\begin{array}{c}\text { Číslo } \\
\text { Vitrea }\end{array}$ & typ & Li & B & $\mathrm{TiO}_{2}$ & $\mathrm{CoO}$ & $\mathrm{Ni}$ & $\mathrm{Zn}$ & As & $\mathbf{R b}$ & $\mathrm{Sr}$ & $\mathrm{Zr}$ & $\mathrm{Ba}$ & $\mathrm{PbO}$ \\
\hline 1991 & heterogenní hmota & LoD & 42,39 & 1121,46 & 6,01 & 9,01 & 92,25 & 2,30 & 496,99 & 513,20 & 43,52 & 1501,31 & $<$ LoD \\
\hline 1992 & vrstva skla v pánvi & $<$ LoD & 130,49 & 2471,84 & 28607,39 & 123,17 & 126927,5 & 30,59 & 436,20 & 592,61 & 131,13 & 5825,58 & 21182,41 \\
\hline 1994 & $\begin{array}{l}\text { heterogenní vrstva } \\
\text { skla v pánvi }\end{array}$ & $<$ LoD & 96,75 & 1926,92 & 77,87 & 19,84 & 261,15 & 2,30 & 496,76 & 731,80 & 56,93 & 2483,01 & 8,45 \\
\hline 1995 & vrstva skla v pánvi & $<$ LoD & 93,62 & 641,93 & 25,88 & 22,49 & 265,49 & $<$ LoD & 617,98 & 1154,37 & 16,14 & 3729,95 & 11,34 \\
\hline 1996 & skelná hmota & 46,41 & $<$ LoD & 2679,00 & 18,02 & 10,82 & 172,37 & $<$ LoD & 561,63 & 263,89 & 62,59 & 1023,99 & 6,10 \\
\hline 1997 & vrstva skla v pánvi & $<$ LoD & 168,51 & 1194,29 & $<$ LoD & 24,61 & 322,36 & 2,81 & 634,34 & 1251,32 & 33,63 & 4342,30 & 17,76 \\
\hline 1998 & skelná hmota & $<$ LoD & 48,29 & 2829,79 & 57,49 & 17,84 & 183,59 & 2,22 & 356,33 & 802,44 & 72,40 & 2867,22 & 17,51 \\
\hline 1999 & vrstva skla v pánvi & $<$ LoD & 26,94 & 3798,57 & 2084,18 & 55,49 & 918,60 & 7,44 & 484,55 & 856,37 & 91,84 & 2854,08 & 55,53 \\
\hline 2000 & vrstva skla v pánvi & $<$ LoD & 90,77 & 607,64 & 24,76 & 21,36 & 253,07 & $<$ LoD & 567,00 & 1086,90 & 15,71 & 3502,52 & 10,87 \\
\hline 2001 & vrstva skla v pánvi & $<$ LoD & 82,23 & 640,13 & 32,19 & 21,47 & 262,45 & $<$ LoD & 593,39 & 1108,61 & 16,15 & 3435,04 & 11,80 \\
\hline 2002 & vrstva skla v pánvi & $<$ LoD & $<$ LoD & 4838,41 & 929,97 & 83,75 & 705,35 & 4,53 & 427,85 & 864,91 & 127,63 & 2750,43 & 36,60 \\
\hline 2003 & vrstva skla v pánvi & $<$ LoD & $<$ LoD & 3061,47 & 61,54 & 16,45 & 80,12 & $<$ LoD & 450,35 & 619,83 & 93,60 & 2450,43 & 4,07 \\
\hline 2004 & vrstva skla v pánvi & $<$ LoD & $<$ LoD & 2679,05 & 876,50 & 52,73 & 687,12 & 6,44 & 627,33 & 599,22 & 74,30 & 1950,82 & 104,02 \\
\hline 2005 & skelná hmota & 582,59 & 32,93 & 2805,66 & 13,03 & 9,06 & 310,17 & $<$ LoD & 594,65 & 209,08 & 71,65 & 791,40 & 7,77 \\
\hline 2006 & skelná hmota & 234,48 & $<$ LoD & 2558,42 & $<$ LoD & 11,62 & 247,43 & $<$ LoD & 572,88 & 304,92 & 63,34 & 1099,49 & 6,94 \\
\hline 2007 & skelná hmota & 43,90 & 48,58 & 2189,57 & 107,76 & 23,87 & 362,69 & 3,75 & 484,19 & 841,93 & 58,67 & 3069,30 & 16,11 \\
\hline 2008 & kapka & 40,45 & 48,41 & 2879,68 & 16,86 & 22,14 & 195,41 & 2,99 & 448,42 & 763,57 & 75,00 & 3312,91 & 15,94 \\
\hline 2009 & skelná hmota & 79,91 & 65,28 & 2135,94 & 31,60 & 17,36 & 190,60 & 2,29 & 374,20 & 888,95 & 53,95 & 3280,30 & 7,80 \\
\hline 2010 & kapka & 43,72 & 33,40 & 2210,14 & 82,98 & 13,74 & 292,93 & 1,58 & 542,52 & 456,76 & 59,70 & 1904,87 & 6,39 \\
\hline 2011 & kapka & 55,83 & 40,00 & 2765,48 & 26,58 & 15,74 & 219,04 & 2,91 & 511,30 & 572,29 & 69,06 & 1969,05 & 8,84 \\
\hline 2012 & kapka & 44,10 & 9,53 & 1137,90 & 17,34 & 31,83 & 548,65 & 3,31 & 645,41 & 77,94 & 42,71 & 278,56 & 3,79 \\
\hline 2013 & skelná hmota & 634,11 & 39,29 & 2110,68 & 13,84 & 9,23 & 226,07 & $<$ LoD & 404,17 & 304,37 & 49,04 & 1122,69 & 12,26 \\
\hline 2014 & skelná hmota & $<$ LoD & 36,43 & 2444,69 & $<$ LoD & 15,01 & 297,08 & $<$ LoD & 613,48 & 535,03 & 68,11 & 2253,10 & 5,20 \\
\hline 2015 & skelná hmota & 41,04 & 47,14 & 2435,01 & 16,32 & 17,45 & 314,56 & $<$ LoD & 649,73 & 589,21 & 68,73 & 2341,20 & 7,13 \\
\hline 2016 & skelná hmota & 45,92 & 40,01 & 2675,10 & 26,90 & 13,70 & 226,19 & $<$ LoD & 610,54 & 418,36 & 70,67 & 1583,80 & 4,22 \\
\hline 2017 & kapka & 148,12 & 31,34 & 1130,55 & $<$ LoD & 13,93 & 408,01 & $<$ LoD & 663,74 & 141,30 & 35,16 & 514,98 & 8,37 \\
\hline 2018 & skelná hmota & 343,00 & $<$ LoD & 1853,93 & $<$ LoD & 12,67 & 312,25 & 14,54 & 539,09 & 298,69 & 53,23 & 1087,67 & 13,18 \\
\hline 2019 & skelná hmota & 42,99 & 32,73 & 3355,91 & 13,31 & 14,43 & 154,94 & 2,09 & 543,21 & 530,67 & 80,52 & 1957,10 & 5,86 \\
\hline 2020 & skelná hmota & 53,13 & 68,42 & 2114,64 & 36,97 & 18,33 & 238,05 & 3,65 & 518,85 & 801,70 & 58,99 & 2826,44 & 12,31 \\
\hline 2021 & skelná hmota & 38,52 & 29,65 & 2178,19 & 7,50 & 15,39 & 292,53 & $<$ LoD & 560,30 & 448,61 & 59,40 & 1725,55 & 4,15 \\
\hline 2022 & skelná h & 35,97 & 34,67 & 233 & 13,82 & 13,58 & 476,64 & 1,50 & 756,00 & 448,30 & 61,41 & 1440,39 & 6,02 \\
\hline 2023 & kapka & 22,92 & 23,68 & 2194,09 & 11,22 & 15,11 & 195,70 & 1,76 & 627,98 & 485,25 & 59,91 & 1750,12 & 5,90 \\
\hline 2024 & skelná hmota & 594,66 & 17,88 & 1885,46 & 11,96 & 13,91 & 311,83 & 2,36 & 571,22 & 307,73 & 52,94 & 1036,52 & 6,96 \\
\hline 2025 & kapka & 28,24 & 46,44 & 2736,51 & 12,45 & 23,24 & 198,06 & 2,13 & 427,10 & 758,10 & 74,09 & 3490,93 & 8,39 \\
\hline 2038 & $\begin{array}{l}\text { heterogenní vrstva } \\
\text { skla v pánvi }\end{array}$ & $<$ LoD & 72,37 & 1463,12 & 39,59 & 13,21 & 183,61 & 2,13 & 339,87 & 694,58 & 37,42 & 1528,87 & 6,73 \\
\hline 1531 & terčík & 32,00 & 244,00 & 0,14 & 4,00 & 23,00 & 235,00 & 3,00 & 44,00 & 892,00 & 101,00 & 3128,22 & 8,59 \\
\hline
\end{tabular}

Tab. 9b. Chemické složení indikátorů sklářské výroby; LA-ICP-MS (obsahy vybraných prvků v ppm). Tab. 9b. chemical composition of glass production indicators; LA-ICP-MS (contents of selected elements in ppm).

\begin{tabular}{|c|c|c|c|c|c|c|c|c|c|c|c|}
\hline $\begin{array}{c}\text { Č́slo } \\
\text { Vitrea }\end{array}$ & typ & $\mathrm{Cu} \%$ & $\mathrm{~Pb} \%$ & $\mathrm{Co}(\mathrm{ppm})$ & $\mathrm{Ni}(\mathrm{ppm})$ & $\mathrm{Zn}(\mathrm{ppm})$ & As (ppm) & Sn (ppm) & Sb (ppm) & Bi (ppm) & Ag (ppm) \\
\hline 2037 & relikt kovu & 80,65 & 15,77 & 1393 & 3429 & 1373 & 1819 & 5897 & 19708 & 114 & 1920 \\
\hline
\end{tabular}

Tab. 9c. Chemické složení reliktu kovu.

Tab. 9c. Chemical composition of metal residue. 
(viz níže). U vzorku č. 1992 došlo k částečnému zkreslení složení skla vlivem přítomného kovu, v analýze bylo např. stanoveno enormní množství zinku (12,7 \% Zn). V př́ípadě druhého vzorku byla provedena dvě měření (č. 1994 a č. 2038), v nichž se samozřjejmě také projevila nehomogenita vrstvy (tab. 9). Jako konkrétní př́klad lze uvést rozdílný obsah CaO u analýzy č. 2038 (26,8 \%) oproti analýze č. 1994 (20,4 \%).

Je zřejmé, že i vzorky, které makroskopicky nevypadají jako sklo, mohou poskytnout určitou informaci o složení skla ve smyslu protikladu sklo draselné versus sodné, popř. o používaných barvicích surovinách.

\subsection{Vrstvy skla na vnitřním povrchu pánví}

Chemické složení skel z vnitřních stěn pánví mohou negativně ovlivnit určité faktory. Mezi ně patří v prvé řadě nízká chemická odolnost skla tohoto období. Výsledky analýz tenkých vrstev skla prokázaly, že v těchto případech došlo vlivem okolního prostředí k vyloužení alkálií, a tak k relativnímu nadhodnocení oxidu křemičitého. Tento děj (korozi skla) lze současně doložit u zbytků skel na silnostěnných pánvích (obr. 12 a 14), kdy horní část vrstvy je tvořena silnou nahnědlou korozní krustou se složením až $10 \mathrm{hm}$. $\% \mathrm{Al}_{2} \mathrm{O}_{3}$, přes $80 \mathrm{hm} . \% \mathrm{SiO}_{2}$ a ca $1,5 \mathrm{hm} . \% \mathrm{Fe}_{2} \mathrm{O}_{3}$. Metodou XRD nebyly v této hmotě detekovány žádné krystalické fáze (Cílová 2008). Problémem může být též kontaminace skla materiálem pánve - především v podobě $\mathrm{Al}_{2} \mathrm{O}_{3}, \mathrm{SiO}_{2} \mathrm{a} \mathrm{Fe}_{2} \mathrm{O}_{3}$.

Kromě těchto oxidů mohou do skloviny při tavení přejít i další složky žáromateriálu (Smrček a kol. 2008). Skladba reakčních vrstev vzniklých interakcí materiálu pánve a skloviny je uvedena v citované práci následovně: pánvová hmota - reakční pásmo (mullitová vrstva) - sklovité mezivrstvy - sklo (Smrček $a$ kol. 2008, 643). Přestože se jedná o text věnovaný současné problematice, obdobné závěry lze nalézt i v souvislosti s výrazně staršími pánvemi (např. Dungworth 2008). Autor této práce, jejímž předmětem je právě interakce skla s materiálem historických pánví, došel k obdobným závěrům u pánví ze 17. století. Rozlišuje dvě vrstvy mezi sklem a pánví, z toho první (reakční pásmo) popisuje ještě jako část keramického stř̌pu pánve, jejiž složení je nicméně pozměněné oproti základnímu střepu pánve. Kromě odlišného složení vykazuje i nižší míru porozity oproti materiálu pánve. Druhá vrstva (sklovitá mezivrstva nad reakčním pásmem) se projevuje trochu jiným složením oproti vrstvě skla a autor předpokládá, že byla jakousi bariérou/ochranou proti další korozi pánve. Dvě přechodové vrstvy uvádí i G. Eramo (2006) při hodnocení sklářských pánví z přelomu 17.-18. století, a komentuje i skelné vrstvy vznikající v důsledku koroze vnějšího povrchu pánve atmosférou pece, zejména v př́padě, kdy je pec otápěna dřevem a dochází k vypařování alkalických složek dřeva. Analyzované vrstvy jsou především na bázi $\mathrm{SiO}_{2}-\mathrm{Al}_{2} \mathrm{O}_{3}-\mathrm{K}_{2} \mathrm{O}$ a autor vysvětluje př́tomnost $\mathrm{K}_{2} \mathrm{O}(5-12 \mathrm{hm}$.\%) v těchto vrstvách kontaminací vnějšího povrchu pánve draslíkem (ve formě hydroxidu) pocházejícím ze spalovaného dřeva a dále pak i ze surovin sklářského kmene (při vystavení surovin sklářského kmene vyšším teplotám dochází k těkání složek, v případě bukového popele např. draslíku). Zdrojem těchto těkavých složek tedy může být kromě sklářského kmene (surovin), roztavená sklovina a v př́padě pecí otápěných dřevem i samotné dřevo. Reakcí alkalických oxidů s př́tomnými plyny, zejména vodní párou, pak vznikají alkalické hydroxidy (např. $\mathrm{KOH}$, Smrček a kol. 2008, 121-126).

Kontaminace skloviny hmotou pánve je samozřejmě ovlivněna její kvalitou (typem materiálu, stupněm slinutí/porozitou). Nerovnoměrná koroze materiálu se po několika tavbách může projevit plošnou důlkovou korozí (obr. 12-15), což zvýší reakční plochu a urychluje korozní procesy. Jako další faktory se uvádí např. výše tavící teploty a viskozita skloviny (Eramo 2006). Pro odběr vzorku jsou tedy optimální silnější vrstvy skla, u kterých se popisované faktory tolik neprojeví a středová část vrstvy může poskytnout poměrně spolehlivá data. Metodou elektronové skenovací mikroskopie lze tyto přechodové vrstvy i zdokumentovat (obr. 16) a dosahují tlouštěk až $400 \mu \mathrm{m}$ (platné pro uvedený snímek). 


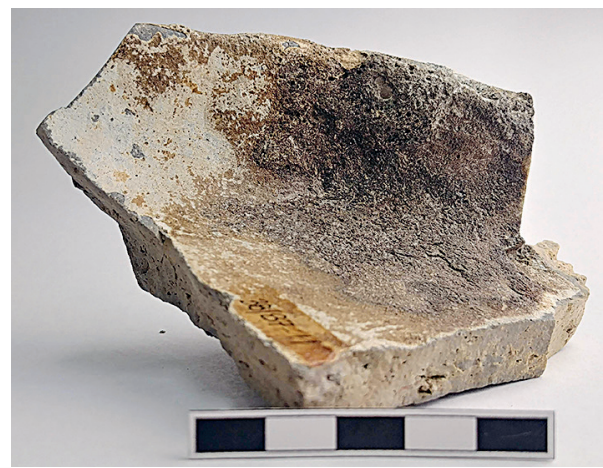

Obr. 9. Pánev s hnědou opakní vrstvou; detail vrstvy na řezu na následujícím obrázku.

Fig. 9. Melting pot with brown opaque layer; detail of layer in cross-section in the following figure.

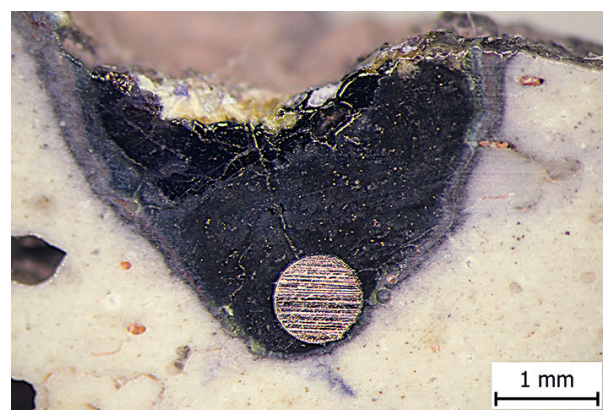

Obr. 11. Nábrus vzorku č. 1992, patrné zbytky modrého skla a kovová inkluze.

Fig. 11. Polished section of sample no. 1992, visible residues of blue glass and metal inclusion.

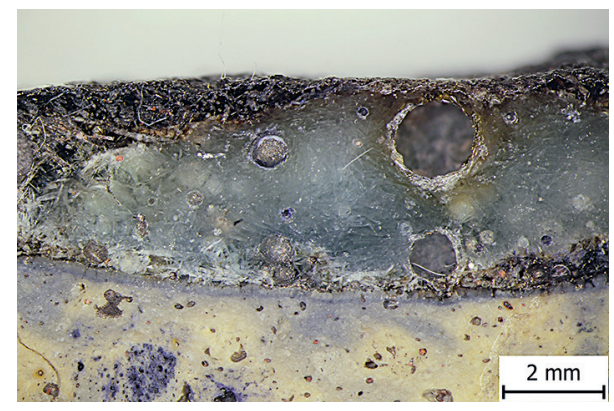

Obr. 10. Nábrus vzorku č. 1994, nehomogenní charakter vrstvy zelenomodré barvy, v dolní části snímku je patrná tavící pánev.

Fig. 10. Polished section of sample no. 1994, inhomogeneous character of layer with a green-blue colour; a melting pot appears in the lower part of the photo.

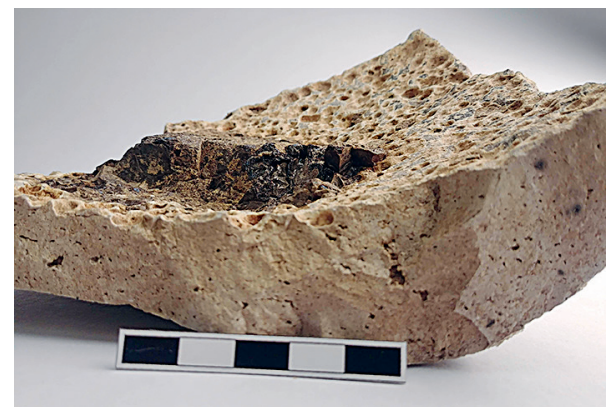

Obr. 12. Pánev s vrstvou silně zkorodovaného skla (př. č. 93/86-11). Povrch pánve je silně poškozen $\checkmark$ důsledku působení skloviny při tavení skla.

Fig. 12. Melting pot with layer of heavily corroded glass (acc. no. 93/86-11). The surface of the pan is heavily damaged due from the effect of the molten glass as the glass was being melted.

V naší práci jsou hodnoceny tři typy vrstev lišící se jednoznačně barvou a tlouštkou. Zastoupena jsou tedy skla ze silnostěnných pánví - první skupina (vzorky č. 1995, 1997, 2000 a 2001), dále skla modré barvy (tenčí vrstvy) z menších pánviček s tenčím střepem (druhá skupina; č. 1999, 2002, 2004) a vrstva zeleného skla z menší pánvičky (č. 2003). Trochu specifický je vzorek č. 1992 (popsán výše). Nejedná se přímo o viditelnou vrstvu skla na povrchu pánve, ale pod vrstvou hlinito-křemičitého hnědošedého materiálu, byly nalezeny zbytky skla modré barvy, a dokonce vyredukovaná částice kovu. Z chemického hlediska lze tyto tři skupiny popsat následovně:

Skla ze silnostěnných pánví mají obsahy majoritně zastoupených oxidů tyto: $\mathrm{K}_{2} \mathrm{O}$ $18,9 \mathrm{hm} . \%, 20,8 \mathrm{hm} . \% \mathrm{CaO}$ a $52,3 \mathrm{hm} . \% \mathrm{SiO}_{2}$ (uvedeny průměrné hodnoty pro danou skupinu), poměr $\mathrm{CaO} / \mathrm{K}_{2} \mathrm{O} \sim 1,1$. Obsahy $\mathrm{Al}_{2} \mathrm{O}_{3}$ jsou ca $1 \mathrm{hm} . \%$, obsahy $\mathrm{MgO}$ ca $3,5 \mathrm{hm} . \%$ a $\mathrm{P}_{2} \mathrm{O}_{5} 1,6$ hm.\%. Složení skupiny modrých skel je poměrně konzistentní, obsahy $\mathrm{SiO}_{2}$ 


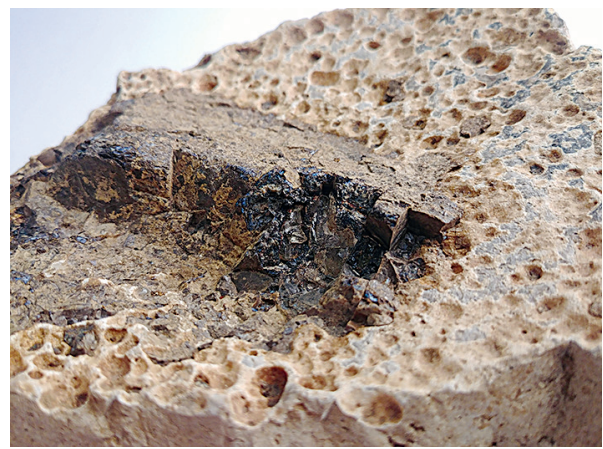

Obr. 13. Detail z předchozího obrázku se zbytky skla - ve středové části (viz analýza č. 1995).

Fig. 13. Detail from fig. 12 with residues of glass in the middle part (see analysis no. 1995).

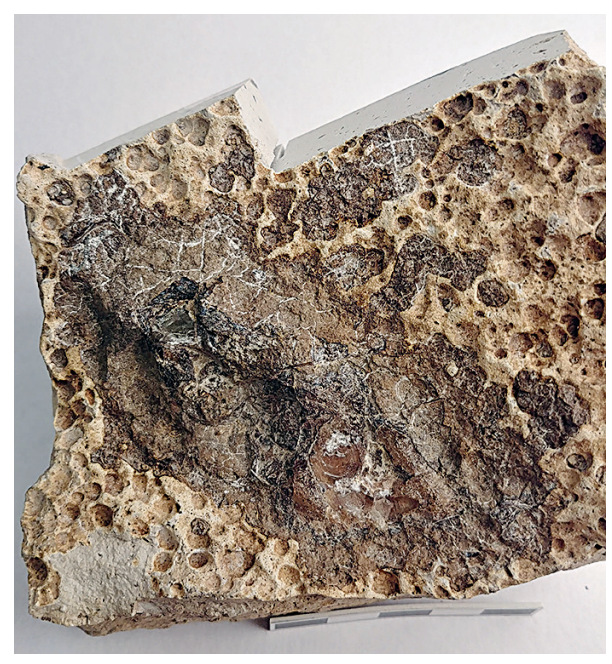

Obr. 15. Detail z předchozího obrázku se zbytky skla; patrná dvě místa odběru (tab. 9, analýzy č. 2000 a 2001).

Fig. 15. Detail from fig. 14 with residues of glass; two collection sampling points visible (tab. 1, analysis nos. 2000 and 2001).

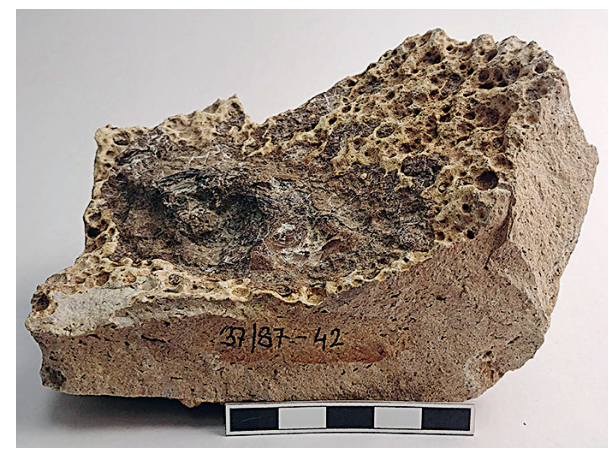

Obr. 14. Pánev s vrstvou silně zkorodovaného skla (př. č. 37/87-42).

Fig. 14. Melting pot with layer of heavily corroded glass (acc. no. 37/87-42).

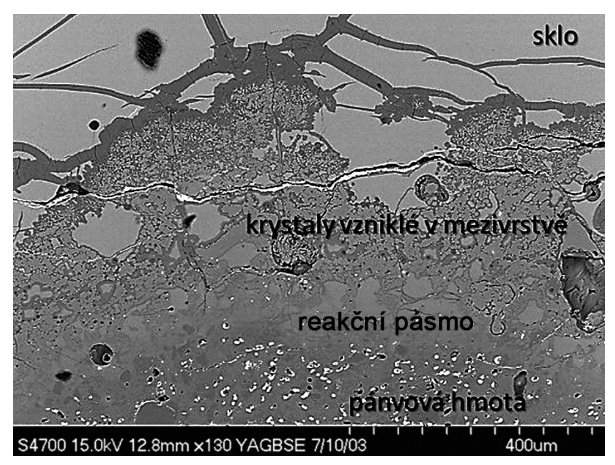

Obr. 16. Dokumentace výsledku interakce skloviny s hmotou pánve na nábrusu vzorku; dole na snímku je pánvová hmota, středová část - krystaly vzniklé v mezivrstvě mezi sklovinou a materiálem pánve, šedé plochy v horní části snímku - sklo.

Fig. 16. Documentation of the interaction of the molten glass with the material on the polished section of the sample; at the bottom of the photo is the pot material, the middle part-crystals formed in the interlayer between the molten glass and the pot material, the grey area in the upper part of the photo - glass.

jsou oproti předchozí skupině vyšší (ca $60 \mathrm{hm} . \%$ ), zrovna tak $\mathrm{Al}_{2} \mathrm{O}_{3}$ (ca 4,6 hm.\%). To by mohlo být způsobeno i vyšší kontaminací skla z materiálu pánve. Sklo je opět draselno-vápenaté, nicméně s nižším zastoupením $\mathrm{K}_{2} \mathrm{O}(14 \mathrm{hm} . \%)$ i $\mathrm{CaO}(12,8 \mathrm{hm}$.\%) a poměrem $\mathrm{CaO} / \mathrm{K}_{2} \mathrm{O} 0,9$. Téměř poloviční je hodnota $\mathrm{P}_{2} \mathrm{O}_{5}$. Rozdíly lze najít i v obsahu $\mathrm{TiO}_{2}$, který u modrých skel dosahuje až $0,4 \mathrm{hm}$.\%, zatímco u skel první skupiny max. $0,1 \mathrm{hm} . \%$. Dalším prvkem, který je vnášen především křemennou surovinou, je zirkon a rozdíly v jeho obsahu jsou do 34 ppm u první skupiny a průměrně 98 ppm u druhé skupiny (u modrých skel). Přestože složení každé skupiny je poměrně konzistentní a výše popisujeme určité 
rozdíly mezi skupinami, je nutné přihlédnout k faktu, že kvůli probarvení modrého skla musela být nutně přidána další surovina, která mohla vnést nejenom barvicí, ale i další prvky. Složky, které jednoznačně ovlivňují barevnost skla, jsou zde oxidy mědi a kobaltu. V modrých sklech jsou zastoupeny v množstvích stovek až tisíců ppm CoO a 0,5 až dokonce 2,9 hm.\% CuO. Oproti tomu skla první skupiny (úmyslně nezabarvená) obsahují CoO v rozmezí jen desítek ppm a stovky ppm $\mathrm{CuO}$ (max. hodnota 120 ppm). Oxidy mědi v tomto množství odpovídají jejich vnesení rostlinným popelem. Na výslednou barvu má samozřejmě vliv i vnesené železo, které je složkou jak křemenných surovin, tak popele a možná i barvicí suroviny. Pokud srovnáme výsledky analýz obou skupin skel, můžeme usuzovat na další prvky vnesené barvicí surovinou: $\mathrm{Ni}, \mathrm{Zn}, \mathrm{Sn}, \mathrm{Sb}$ (obsahy těchto prvků v desítkách až stovkách ppm byly určeny metodou LA-ICP-MS); zvýšené je i množství prvků vzácných zemin (REE). Jak bylo uvedeno výše, ve vzorku č. 1992 byla nalezena i částice vyredukovaného kovu. Analýzou LA-ICP-MS bylo zjištěno, že je v ní majoritně zastoupena měd' $(81$ hm. \% Cu) v menší míře olovo (16\%), v hodnotě $2 \%$ antimon a do $1 \% \mathrm{Co}, \mathrm{Ni}$, $\mathrm{Zn}, \mathrm{As}, \mathrm{Ag}$ a Sn.

Posledním vzorkem ke zhodnocení je vrstva zelené barvy (analýza č. 2003), která celkovým složením více koresponduje se skly modrými než nezabarvenými z větších silnostěnných pánví. Podle výše uvedených informací se přikláníme k názoru, že v lokalitě byly taveny nejméně dvě varianty draselno-vápenatých skel, které lze rozlišit již na základě majoritně zastoupených složek $\mathrm{K}_{2} \mathrm{O}-\mathrm{CaO}-\mathrm{SiO}_{2}$. Vzhledem $\mathrm{k}$ faktu, že v lokalitě nebyl nalezen jediný fragment finálního výrobku, lze na složení používaného skla usuzovat pouze z dostupných dat týkajících se indikátorů výroby skla. V př́padě některých vzorků skel odebraných z pánví předpokládáme kontaminaci skloviny především oxidem křemičitým a hlinitým. Vyšší obsahy obou oxidů byly zaznamenány u modrých skel - až 5,5 hm.\% $\mathrm{Al}_{2} \mathrm{O}_{3}$ a $62,4 \mathrm{hm} . \% \mathrm{SiO}_{2}$ oproti max. stanovené hodnotě $\mathrm{Al}_{2} \mathrm{O}_{3}(1,6 \mathrm{hm} . \%)$ a $53,6 \mathrm{hm} . \%$ $\mathrm{SiO}_{2}$ u první skupiny skel.

Již publikované hodnoty těchto oxidů jsou pro finální výrobky 13.-14. století z oblasti severozápadních Čech následující: $\mathrm{Al}_{2} \mathrm{O}_{3}$ do 2 hm.\% a SiO 2 v širším rozmezí 46-59hm.\% (platné pro Černá 2017). Na základě těchto dat se přikláníme k závěru, že obsahy obou oxidů jsou u skel první varianty reálné a vzhledem k odběru vzorku z míst vzdálenějších od pánve nedošlo k výraznější kontaminaci skloviny. Skla druhé varianty (modrá) sice hodnotu $\mathrm{Al}_{2} \mathrm{O}_{3}$ převyšují, ale $\mathrm{z}$ naměřených dat lze získat informaci, že se v pánvi tavilo draselno-vápenaté sklo s přídavkem popela (vyšší obsahy $\mathrm{P}_{2} \mathrm{O}_{5} \mathrm{i} \mathrm{MgO}$ ).

Pro skla, při jejichž výrobě byl použit popel stromů, doporučují pro jejich bližší specifikaci autoři prací (Geilmann 1954; Wedepohl - Simon 2010; Degryse - Shortland 2020) následující prvky: Sr, Rb, Zn, Ni, Cu, B, Ba a Mn. Důležitým markerem použítí popele je stroncium v řádech několika stovek až tisíce ppm ve skle; hodnoty pod 200 ppm Sr by naznačovaly použití vápence (Degryse - Shortland 2020). U vzorků první skupiny jsou tyto hodnoty ca 1150 ppm Sr a u vrstev skel modré a zelené barvy v rozmezí ca 600-900ppm (tab. 9), což souhlasí s daty v literatuře (Wedepohl - Simon 2010).

\subsection{Indikátory výroby (kapky a vlákna)}

Kapky a vlákna nalezené v blízkosti sklářských pecí jsou bezpečnými indikátory výroby skla. Pokud budeme vycházet ze složení vrstev skla na pánvích první skupiny, pak je zřejmé, že všechny hodnocené kapky mají poměrně vysoký obsah $\mathrm{SiO}_{2}$ (přes 60 hm.\%) 
a některé dosahují dokonce téměř $80 \mathrm{hm}$.\% tohoto oxidu. Naopak hodnoty alkálií jsou u vzorků nižší; pro $\mathrm{CaO}$ v rozmezí 1-14 hm.\% a 8-17 hm.\% pro $\mathrm{K}_{2} \mathrm{O}$. Především některé hodnoty pro oxid vápenatý jsou př́liš nízké a lze se domnívat, že tyto kapky vznikly zřejmě reakcí materiálu prrítomného ve vyzdívkách komory pece s její atmosférou (více např. Kurzmann 2004, 281-283). Uvedený závěr lze podložit i obsahem $\mathrm{P}_{2} \mathrm{O}_{5}$, který dosahuje u těchto vzorků hodnot do ca 0,5 hm.\% (oproti očekávanému ca 1 hm.\% a více). V analýzách jsou oproti průměrným hodnotám skel námi klasifikované první skupiny zastoupeny v menším množství i další prvky, na př́klad Sr je pouze do ca 500 ppm oproti 1100 ppm a baryum někdy dosahuje dokonce jen stovky ppm oproti 3900 ppm. Na základě těchto dat lze konstatovat, že pouze malá část vzorků kapek a slitků se přibližuje svým složením finálnímu sklu tavenému v této sklárně.

Drobné nálezy kapek a amorfní skelné hmoty, u nichž se předpokládá náhodný vznik náhodně v prostoru tavicí pece, uvádějí Paynter a Dungworth (2018) a Wilke a Stephan (2020). Wilke a Stephan ve své studii publikovali výsledky analýz kapek jak z karolinské sklárny blízko Bodenfelde, tak i z mladší lokality v oblasti Kleiner Mittelberg datované do rozpětí let 1230-1250 (Wilke - Stephan 2020). Obsahy $\mathrm{K}_{2} \mathrm{O}$ oproti CaO v analyzovaných vzorcích byly opět vysoké, $\mathrm{CaO}$ byl většinou zastoupen do $5 \%$. Vzhledem k vysokým hodnotám $\mathrm{SiO}_{2}$ u některých vzorků se autoři domnívají, že z velké části tyto kapky nereprezentují složení skla taveného na dané sklárně. Toto dokládají další příklady ze stř̌edověké sklárny (1420-1440) blízko Bodenfelde, odtud byly opět analyzovány kapky a amorfní skelné kusy ve srovnání s fragmenty již hotových výrobků a pouze část amorfních skelných vzorků bylo možné srovnat se složením hotových výrobků (vzorky ve formě kapek toto spíše nesplňovaly). Oba autoři Wilke a Stephan se dále zabývali možností, zda nebyl použit sklářský kmen ve složení určité formy potaše a křemene. Z našich dat vyplývá, že kapky mají minimálně $3 \% \mathrm{Al}_{2} \mathrm{O}_{3}$. Pokud bychom zvažovali jako citovaní autoři možnost tavení potaše a křemene, pak by nebylo jasné, jakým způsobem se do kapek dostal oxid hlinitý $\left(\mathrm{Al}_{2} \mathrm{O}_{3}\right)$ v tak vysokém množství. Analýzou křemene nalezeného při výzkumu objektu č. 6 na sklárně Jilmová I (analyzováno pouze jedno zrno ze vzorku skla 75 - srov. Cúlová 2008) bylo zjištěno, že se jedná o poměrně čistý zdroj oxidu křemičitého $\left(98,7 \% \mathrm{SiO}_{2}\right)$ s obsahem $\mathrm{Al}_{2} \mathrm{O}_{3} 0,8 \%$ a $\mathrm{Fe}_{2} \mathrm{O}_{3} 0,08 \%$. Experimentálně vyrobená potaš obsahuje max. $0,8 \% \mathrm{Al}_{2} \mathrm{O}_{3}$ (dle dat Cílová - Woitsch 2012; Stern - Gerber 2004), není tedy zřejmé, jak by se $\mathrm{Al}_{2} \mathrm{O}_{3}$ v množstvích 3 a více procent do ,skla“ kapek ze surovin dostal (obdobně např. i $\mathrm{TiO}_{2}$ ).

Srovnání dat týkající se skleněných vrstev v pánvích a indikátorů výroby v podobě kapek/kusů je uvedeno níže na $o b r .17$, který dokumentuje, že tyto vzorky obsahují značné množství $\mathrm{SiO}_{2}$ a se vzorky první skupiny skel z pánví vůbec nekorespondují. Vyšší hodnoty $\mathrm{SiO}_{2}$ byly nalezeny pouze u modrého a zeleného skla pocházejícího z pánve. U těchto vzorků je nutné zvážit zdroj vyššího obsahu obou oxidů. Jak bylo uvedeno výše, mohlo dojít ke kontaminaci skloviny materiálem pánve, v případě modrého skla neznáme surovinu, která vnesla barvící složky. Dalším vysvětlením by mohlo být i užití jiného poměru surovin v kmeni, konkrétně zvýšení množství křemenné složky, což naznačují i vyšší hodnoty $\mathrm{TiO}_{2}$ a $\mathrm{Zr}$ u skupiny skel modré a zelené barvy. Lze předpokládat, že skláři měli zkušenosti spíše empirického charakteru a vzhledem k variabilitě popele bylo složité obdržet konstantní složení skla. Nicméně obsah $\mathrm{SiO}_{2} \mathrm{v}$ některých indikátorech výroby je př́liš vysoký a tyto vzorky jednoznačně nereprezentují složení skla vyráběného v dané sklárně. Z obr. 17: $a-d$ je zřejmé, že indikátory se svým složením výrazně liší od skel odebraných z pánví první skupiny a pouze malá část (vzorky č. 2007, 2009, 2020) koresponduje se 
vzorky skel skupiny druhé (modré a zelené barvy). Toto dobře dokumentuje především obr. 17: $d$, kde je patrné, že s hodnotou ca 65 hm.\% SiO dochází k výraznému poklesu poměru $\mathrm{CaO} / \mathrm{K}_{2} \mathrm{O}$. Určit hranici obsahu $\mathrm{SiO}_{2}$, u které lze ještě mluvit o finálním skle ze sklárny Jilmová, je v př́padě kapek poměrně složité. Toto určení dále komplikuje zastoupení pouze určitých artefaktů v souboru bez vzorku finálního předmětu/výrobku. Jak bylo uvedeno výše, pro skla 13.-14. století z oblasti severozáp. Čech (publikována data pro menší soubor), uvádí Černá (2017) hodnoty $\mathrm{SiO}_{2}$ do 59 hm.\%. Je nutné si i uvědomit, že na mladších sklárnách, např. Moldavě I (datované do přelomu 14. a 15. století) jsou u finálních výrobků hodnoty $\mathrm{SiO}_{2} 58,2 \pm 4,1$ hm.\% (Cílová 2008). Je spíše nepravděpodobné, že by byli skláři na starší sklárně schopni utavit skla s vyššími hodnotami oxidu křemičitého.

Grafy jsou doplněny daty vzorků (převzato z Jonášová 2016), u kterých bylo předpokládáno, že reprezentují artefakty vzniklé při procesu tvarování skla na sklárně Jilmová. Z jednotlivých grafů je znatelné, že se tyto vzorky opět neshodují se vzorky první skupiny skel z pánví a složení jen části z nich by mohlo být považováno za sklo/sklovinu, které bylo zpracováváno skláři při tvarování výrobků. Řada vzorků neobsahuje ani 10 hm.\% CaO, což se projevuje i v nevyhovujících hodnotách $\mathrm{CaO} / \mathrm{K}_{2} \mathrm{O}$, dále jsou nízké obsahy $\mathrm{P}_{2} \mathrm{O}_{5}$ (i $0,3 \mathrm{hm} . \%$ ), naopak některé vzorky obsahují až $66 \mathrm{hm} . \% \mathrm{SiO}_{2}$. Je evidentní, že rozlišení indikátorů výroby, a dokonce přiřazení k jednotlivým technologickým operacím není snadné.

Odlišná data poskytl vzorek s označením 1531, což je dáno rozdílným stářím analyzovaného artefaktu. Pochází z raně novověkého okenního terčíku nalezeného ve vrstvách 16.-17. století (viz výše). Analýzou byl stanoven vysoký obsah $\mathrm{CaO}(24,5 \%)$ a poměrně nízký obsah $\mathrm{K}_{2} \mathrm{O}(4,5 \%)$. Obsah $\mathrm{SiO}_{2} 57,3$ \% je o něco vyšší oproti sklům/vrstvám skel pocházejících z pánví první skupiny. Rozdíl ve složení je i v obsahu $\mathrm{P}_{2} \mathrm{O}_{5}$, kdy u vzorku 1531 je 2,9 \% a u vzorků z pánví 1,6 \% $\mathrm{P}_{2} \mathrm{O}_{5}$. Tento vzorek je naprosto odlišný od výše řešených skel. V literatuře se s tímto typem skla však setkáváme, bývá označen zkratkou HLLA (high lime low alkali) a platí pro něj, že poměr $\mathrm{CaO} /\left(\mathrm{CaO}+\mathrm{K}_{2} \mathrm{O}\right)$ je větší než 0,75 a suma oxidu draselného $\left(\mathrm{K}_{2} \mathrm{O}\right)$ a sodného $\left(\mathrm{Na}_{2} \mathrm{O}\right)$ je menší než $10 \%$ (Adlington et al. 2019). Obě tato kritéria tento vzorek splňuje. Jiné označení používá K. H. Wedepohl (1997), tato skla definuje jako wood ash-lime glass a spojuje je s rokem 1400, nicméně zvažuje i starší výrobu těchto skel, a to již od roku 1300. Produkci spojuje s regionem Spessart.

\subsection{Technická keramika}

\section{Makroskopická charakteristika}

Předmětem studia žárovzdorné keramiky bylo celkem 45 fragmentů (Cílová 2008). Již podle makroskopického hodnocení lze konstatovat, že skláři používali nejméně dva typy pánví lišící se velikostí. Na vnitřním povrchu malých pánviček byly často nalezeny zbytky skla převážně zelených odstínů, v menší míře bylo zastoupeno zabarvení modré.

Druhou skupinu tvoří fragmenty větších pánví. Převažuje šedý až šedožlutý lom pánve, vyskytují se i okrově žluté barvy. Na větších pánvích je často výrazná důlková koroze nebo zbytky skla, které jsou pod hnědočernou silně zkorodovanou krustou (obr. 12-15). Do třetí skupiny byl zařazen vzorek keramického uzávěru a několik pánví, u kterých byl již makroskopicky stanoven hrubší střep. Barva lomu těchto vzorkủ je žlutá nebo žlutohnědá. 


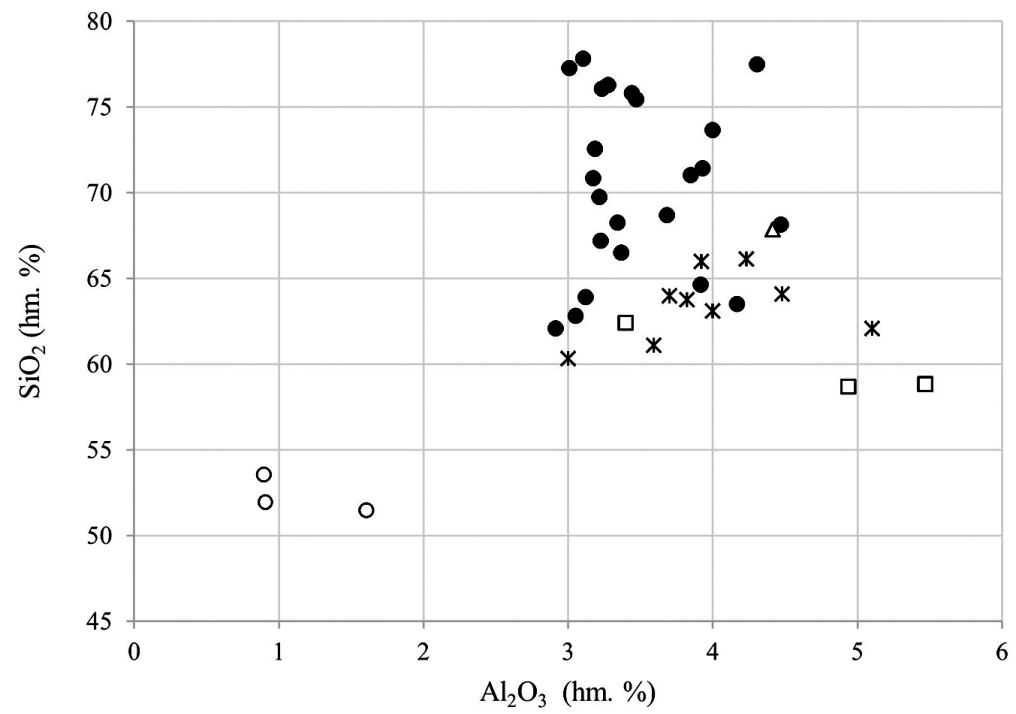

Obr. 17a

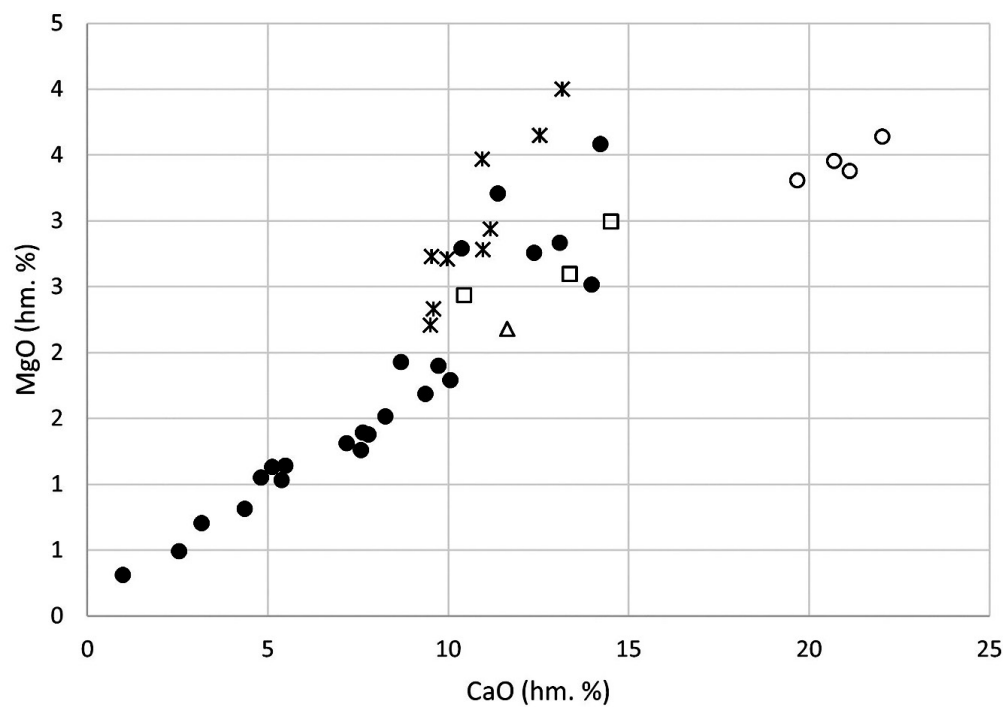

Obr. 17b

Stanovení vlastností střepů

Keramické materiály lze dělit na základě jejich chemicko-mineralogického složení, struktury i použití. Lze u nich měřit nasákavost i další vlastnosti jako jsou zdánlivá pórovitost a objemová hmotnost. Vlivem vyšší pórovitosti dochází u pánví k poklesu mechanické pevnosti, ale i zvýšené interakci systému pánev - tavenina/sklovina, což vede k narušení povrchu pánve.

Nasákavost střepů v souboru je v rozmezí 1,5-8,6\%, hodnoty zdánlivé pórovitosti jsou 3-17,1 \%. Nižší hodnoty nasákavosti jsou pro tavení skla a užitnost pánve lepší. 


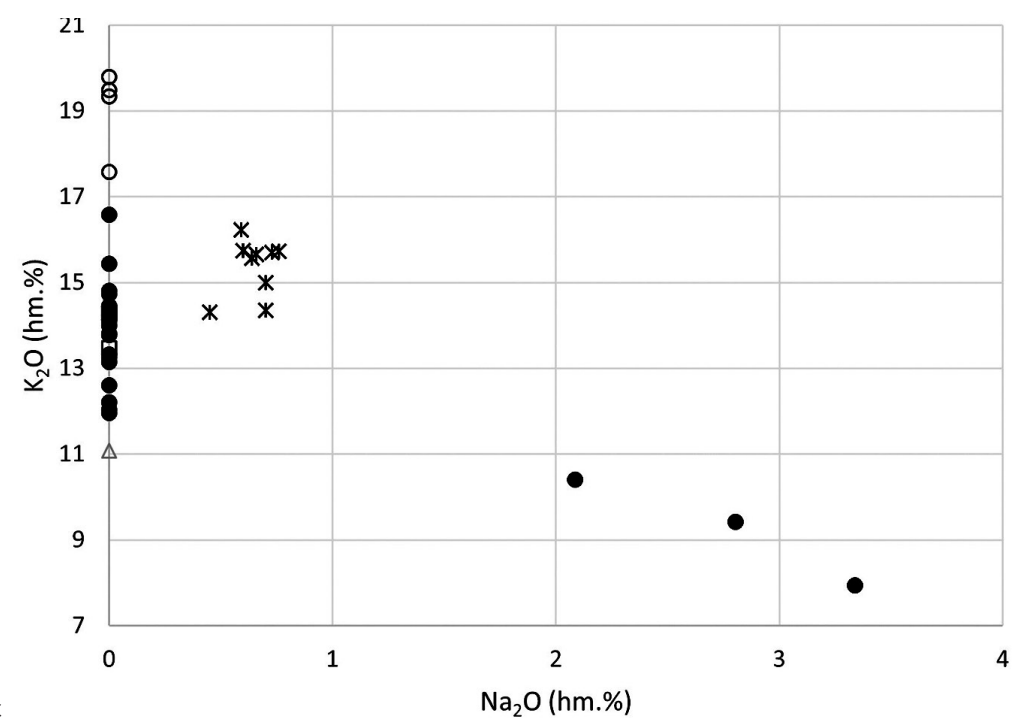

Obr. 17c

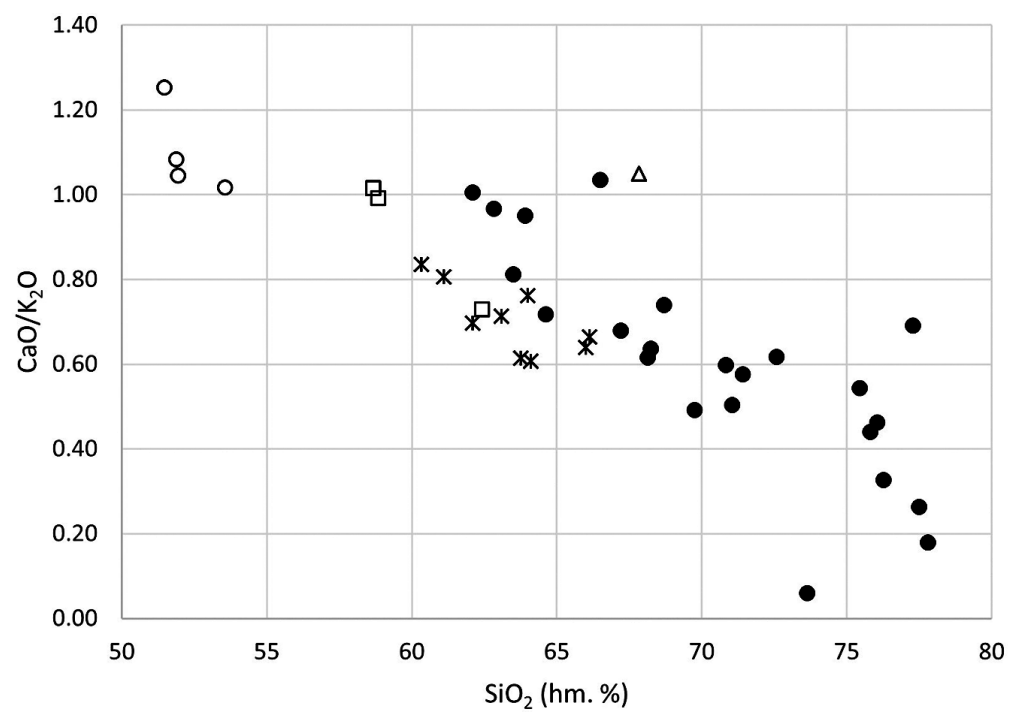

Obr. 17d

Obr. 17. Srovnání vzorků skleněných vrstev z pánví a indikátorů výroby; o - první skupina - vrstvy ze silnostěnných pánví, $\square$ - druhá skupina - vrstvy modrého skla, $\Delta$ - vrstva zeleného skla z pánve, • - indikátory výroby (kapky), *-indikátory výroby ve formě kapek (Jonášová 2016). Nízké obsahy $\mathrm{Na}_{2} \mathrm{O}$ u obr. c jsou dány mezí detekce metody LA-ICP-MS. Lze předpokládat hodnoty do ca $1 \mathrm{hm}$ \%; Charakterizace vzorků (a) dle sítotvorných oxidů, b) dle stabilizátorů skla, c) dle taviv; d) závislost mezi $\mathrm{CaO} / \mathrm{K}_{2} \mathrm{O}$ a $\mathrm{SiO}_{2}$.

Fig. 17. Comparison of samples of glass layers from melting pots and production indicators; $\bigcirc-$ first group layers from thick-sided pots; $\square-$ second group - layers of blue glass; $\Delta$ - layer of green glass from pot; - - production indicators (drops), * - production indicators in the form of drops (Jonášová 2016). Low $\mathrm{Na}_{2} \mathrm{O}$ content in fig. $\mathrm{C}$ is the result of the detection limit of the LA-ICP-MS method. Values up to c. wt\% can be assumed. Characterisation of samples: a) according to network-forming oxides, b) according to glass stabilisers, c) according to fluxes; d) relationship between $\mathrm{CaO} / \mathrm{K}_{2} \mathrm{O}$ and $\mathrm{SiO}_{2}$. 
Výše uvedené vlastnosti byly konfrontovány s měřením metodou polarizační mikroskopie, která potvrdila horší kvalitu vzorků s nejvyššími hodnotami nasákavosti. Ve střepu těchto vzorků bylo nalezeno velké množství hrubších popraskaných křemenů. Zajímavé bylo nalezení úlomků střepů pánví ve hmotě. Drcené stř̌epy již použitých pánví měly zřejmě funkci ostřiva a svědčí o určitém technologickém pokroku při výrobě pánví. Základní surovinou byly žárovzdorné jíly.

Chemické a fázové složení studovaných pánví

Pomocí XRD byly ve střepech pánví nalezeny 4 hlavní fáze: mullit, křemen, cristobalit a tridymit (zastoupen pouze v některých střepech pánví). Mimo uvedené krystalické fáze se ve všech vzorcích předpokládá určitý obsah nekrystalických pevných fází a množství pórů.

Z přítomnosti krystalických fází mullitu a cristobalitu lze usuzovat, že většina vzorků souboru byla vystavena teplotám ca $1200{ }^{\circ} \mathrm{C}$ (Eramo 2006). Ze vzájemných hmotnostních procent zastoupených krystalických fází byly nejvyšší obsahy křemene stanoveny u vzorků méně kvalitních pánví, což odpovídá výsledkům získaným pomocí polarizačního mikroskopu.

Metoda RTG fluorescenční analýzy byla použita pro stanovení chemického složení pánví. Hmoty lze na základě obsahu $\mathrm{SiO}_{2}$ a hlinitého označit jako šamot s nízkým obsahem $\mathrm{Al}_{2} \mathrm{O}_{3}$. Kromě oxidů uvedených v tab. 10 byly ve hmotě střepů zastoupeny i další složky; v jednotkách procenta $\mathrm{K}_{2} \mathrm{O}$, v desetinách či setinách $\mathrm{V}_{2} \mathrm{O}_{5}, \mathrm{Cr}_{2} \mathrm{O}_{3}, \mathrm{ZrO}_{2}$ a BaO.

\section{Diskuse}

\section{Korelace výsledků chemického složení skel z Jilmové s výsledky analýz skel z evropských skláren}

Absence výrobků v areálech některých skláren z počátku vrcholného středověku je běžným jevem v širším středoevropském prostoru (Stephan 2020; Wilke - Stephan 2020). V nálezových souborech se běžně vyskytují již diskutované skelné kapky, amorfní slitky nebo fragmenty pánví, zatímco doklady finální produkce zpravidla chybí. Přitom právě na základě analýz vzorků finálních výrobků lze jednoznačně určit typ skla. V případě sklárny Jilmová však byly nalezeny tavicí pánve s vrstvami skla (skupina jedna), které by mohlo odpovídat sklu, jež se na sklárně zpracovávalo. Složením podobný vzorek (slitek skla) pochází ze sklárny Svor datované do konce 13. století (viz č. 1809 v databázi Vitrea). Srovnatelný je obsah $\mathrm{SiO}_{2}\left(49,6 \%\right.$ ), obsahy $\mathrm{K}_{2} \mathrm{O}$ a CaO jsou ca $18 \%$ (poměr $\mathrm{CaO} / \mathrm{K}_{2} \mathrm{O}$ je tedy 1 ), vyšší je obsah $\mathrm{P}_{2} \mathrm{O}_{5}(3,63 \%)$.

Svým složením jsou skla podobná německým sklům typu wood ash glass definovaných pro období 1000-1400 (Wedepohl 1997; Wedepohl - Simon 2010). Autoři v práci používají pro rozlišení skupin skel poměr $\mathrm{CaO} / \mathrm{K}_{2} \mathrm{O}$ a pro tento typ skla je jeho hodnota $1-1,5$ (pro skla z Jilmové je poměr $\mathrm{CaO} / \mathrm{K}_{2} \mathrm{O} \sim 1,1$ ). Srovnatelné jsou i hodnoty $\mathrm{SiO}_{2}$, kdy pro německá skla je obsah $\mathrm{SiO}_{2} 48,9 \pm 5,3 \%$ a pro skla z Jilmové v rozsahu $52-54 \% \mathrm{SiO}_{2}$ (platné pro skupinu 1, viz tab. 9). Určitá variabilita může být dána složením použitých popelů. Chemické složení popelů je totiž velice proměnlivé (Geilmann 1954; Smedley - 
Jackson 2002; Kurzmann 2004, 35; Stern - Gerber 2004; 2009; Jackson - Booth - Smedley 2005; Gerber et al. 2012, 151; Adlington et al. 2019), závisí na mnoha parametrech, jako je podloží, kde rostlina roste, na části zpracované na popel (kmen, větve, kůra, listí), na typu rostliny (buk, dub, kapradí, aj.), a dokonce i v rámci jednoho typu bukového popelu (lišící se lokalitou růstu) byly pozorovány rozdíly ve složení (Stern - Gerber 2004; Cílová - Woitsch 2012). Dalším velice podstatným kritériem je doba uplynulá od výroby popele do jeho použití (vliv skladování popele), vlastnosti popele se totiž mění v čase tím, že postupně „nabírá“ vzdušnou vlhkost, a tak mění fázové složení a zřejmě i hmotnost (Stern - Gerber 2004). Takovýto nestálý, resp. nestandardizovaný produkt je pro výrobu skla s daným/striktním poměrem surovin poměrně komplikovaný. Vzhledem k variabilitě popelů a dalším faktorům jako je vypařování složek sklářského kmene i skloviny, př́ípadně tzv. stahování skloviny (odstraňování povrchové skloviny, často s vysráženými/nerozpuštěnými složkami sklářského kmene) je téměř nemožné určit fixní poměr surovin ve sklářském kmeni používaném skláři (Kurzmann 2004; Stern - Gerber 2009; Jackson Smedley 2008). Výpočet poměru surovin lze vztáhnout pouze na konkrétní složení popele pro konkrétní typ skla (chemickou analýzu), ale nelze jej zobecňovat.

Popis výroby skla v období středověku je uveden v De diversis artibus/Diversarum Artium Schedula, který sepsal Theophilus Presbyter (asi 1123; Kurzmann 2004, 178). Text uvádí i vhodné suroviny, a dokonce jejich doporučený poměr: směs dvou dílů bukového popela a jednoho dílu říčního písku (Kurzmann 2004, 178; Müller 2006, 92; Jackson - Smedley 2008). P. Kurzmann $(2004,183)$ blíže pojednává o výrobě frity dle Theophila a upozorňuje, že nesmí dojít k celkovému roztavení sklářského kmene (pro další zpracování je totiž vhodná drolivá struktura, místy slinutá, umožňující snadné mechanické zpracování). V textu pochopitelně není uvedena teplota tohoto procesu. Laboratorní test, jehož cílem bylo popsat chování kmene ve složení bukový popel : křemenná surovina, je předmětem práce Jackson - Smedley 2008. Do teplot ca $900{ }^{\circ} \mathrm{C}$ je popisován vznik drobivé hmoty/frity, více slinutý vzorek byl obdržen až při teplotách nad $1000{ }^{\circ} \mathrm{C}$. Průběh laboratorní přípravy frity (produkt vzniklý proreagováním sklářského kmene při nižších než tavících teplotách) zmiňuje Kurzmann (2004, 284-287). Studie popisuje chování sklářského kmene ve složení popel + křemenný písek při vystavení směsi postupně narůstající teplotě. Při $600{ }^{\circ} \mathrm{C}$ po dobu 5 hodin nedošlo $\mathrm{k}$ výraznějším změnám, po dalších $5 \mathrm{~h}$ při $800^{\circ} \mathrm{C}$ bylo pozorováno snížení objemu o $34 \%$ a vznikla drobivá, částečně slinutá hmota, ani po dalších $5 \mathrm{~h}$ při $1000{ }^{\circ} \mathrm{C}$ nebyl obdržen materiál podobný strukturou sklu (vzhledem k těkání složek došlo ke snížení objemu směsi ca o 44 \% oproti původnímu množství). Kurzmann $(2004,285)$ i Stephan $(2020,131)$ se domnívají, že je nepravděpodobné, aby se vzhledem $\mathrm{k}$ jeho drobivé struktuře dochoval tento meziprodukt výroby po několik staletí $\mathrm{v}$ zemi (obdobně Paynter - Dungworth 2018).

$\mathrm{V}$ neposlední řadě je vhodné se zamyslet nad poměrem $\mathrm{CaO} / \mathrm{K}_{2} \mathrm{O}$ ve skle. Stern a Gerber (2009) diskutují uvedený poměr a obsah $\mathrm{P}_{2} \mathrm{O}_{5}$ v souvislosti se skupinou 340 vzorků draselno-vápenatých středoevropských skel. Př̆i hodnotě $\mathrm{P}_{2} \mathrm{O}_{5}$ nad $1 \%$ lze usuzovat na vnesení stromového popele; u skel z Jilmové byla hodnota $1,6 \%$ u vzorku ze Svoru dokonce 3,6 \%. Na základě celkového složení i hodnoty $\mathrm{P}_{2} \mathrm{O}_{5}$, lze prokázat použití popele při výrobě skel. Při hodnocení reliktů modrých skel (z vnitřních částí pánví) bylo zjištěno, že hodnota poměru $\mathrm{CaO} / \mathrm{K}_{2} \mathrm{O}$ klesá pod 1 a nižší byly i obsahy $\mathrm{P}_{2} \mathrm{O}_{5}$. Toto mohou být indicie použití další draselné suroviny, jejichž přídavky by pozměnily hodnotu $\mathrm{CaO} / \mathrm{K}_{2} \mathrm{O}$. Přestože se zdá použití potaše (majoritně zastoupen uhličitan draselný $-\mathrm{K}_{2} \mathrm{CO}_{3}$ ) v tomto období jako časné, K. Müller $(2006,99)$ uvádí několik př́kladů s odkazem na její použití v Evropě v 11.-14. století. Jak ovšem bylo uvedeno výše, složení skla z pánví může být ovlivněno řadou faktorů a spolehlivější konstatování o použití potaše by bylo spíše možné na základě analýz finálních výrobků (v souboru zastoupeny nejsou). Zda byla již v tomto období použita draselná surovina - potaš, bude předmětem chystaného srovnání nálezů ze sklárny Jilmová s dalšími soubory středověkých skel. 


\begin{tabular}{|l|l|c|c|c|c|c|}
\hline \multicolumn{1}{|c|}{ Sklárna } & \multicolumn{1}{|c|}{ zdroj } & $\mathrm{Al}_{2} \mathrm{O}_{3}$ & $\mathrm{Fe}_{2} \mathrm{O}_{3}$ & $\mathrm{TiO}_{2}$ & $\mathrm{CaO}$ & $\mathrm{MgO}$ \\
\hline Jilmová I (20 vzorků) & Cílová 2008 & $19,95 \pm 0,89$ & $1,97 \pm 0,60$ & $1,63 \pm 0,16$ & $0,09 \pm 0,01$ & $0,34 \pm 0,03$ \\
\hline Jilmová II (19 vzorků) & Cílová 2008 & $22,50 \pm 1,24$ & $2,05 \pm 0,65$ & $1,73 \pm 0,11$ & $0,12 \pm 0,04$ & $0,38 \pm 0,04$ \\
\hline Jilmová III (6 vzorků) & Cílová 2008 & $26,23 \pm 2,12$ & $2,2 \pm 0,77$ & $1,69 \pm 0,06$ & $0,22 \pm 0,07$ & $0,48 \pm 0,04$ \\
\hline Jilmová & Brabenec - Černá 1991 & 19,95 & 1,51 & 1,73 & 0,17 & 0,12 \\
\hline Jilmová & Brabenec - Černá 1991 & 19,50 & 1,45 & 1,89 & 0,14 & 0,1 \\
\hline Vlčí hora & Brabenec - Černá 1991 & 24,80 & 2,13 & 2,05 & 0,35 & 0,75 \\
\hline Vlčí hora & Kubát - Gelnar 1991 & 19,70 & 1,88 & 0,13 & neuvedeno & neuvedeno \\
\hline Grillenburg & Brabenec - Černá 1991 & 28,60 & 2,30 & 1,29 & 0,28 & 0,04 \\
\hline
\end{tabular}

Tab. 10. Chemické složení pánví z historických sklářských hutí (hm.\%). Vzorky Jilmová I až III měřeny metodou XRF; VŠCHT Praha. Ve vzorcích majoritně zastoupen $\mathrm{SiO}_{2}$ ( $v$ tabulce neuveden).

Tab. 10. Chemical composition of potsans from glassworks (wt\%). Jilmová I, II and III samples measured by XRF; Institute of Chemical Technology in Prague. $\mathrm{SiO}_{2}$ has a majority presence in samples.

\section{Korelace chemického složení pánví z Jilmové s výsledky analýz materiálu pánví z blízkých středověkých skláren}

Zkoumání chemického složení středověkých pánví se v ČR omezuje na severní část země (Brabenec - Černá 1991: Krušné hory; Kubát - Gelnar 1991: Lužické hory; Brabenec 1988: okolí Nového Boru, Rumburku, Chomutova a sklárny Moldava). Převážná část pánví je hodnocena jako kyselé, event. polokyselé. Zatímco kyselé materiály se rozpouštějí snadněji a téměř bez šlír, zásadité materiály (s obsahem $\mathrm{Al}_{2} \mathrm{O}_{3}$ nad $35 \%$, dle Brabenec 1988) mají větší vliv na porušení homogenity skloviny.

Nižší obsahy oxidu hlinitého byly stanoveny u pánví ze sklárny Jilmová I, krajní hodnoty až $29 \%$ u pánví ze sklárny Jilmová III (tab. 10, podrobněji viz Cílová 2008). Obdobně vysoká hodnota tohoto oxidu byla nalezena u vzorku pánve ze sklárny Grillenburg (28,6 \% $\mathrm{Al}_{2} \mathrm{O}_{3}$, srov. Brabenec 1988). Maximální teploty, kterým byly pánve z Jilmové vystaveny, jsou ca $1250-1300{ }^{\circ} \mathrm{C}$ (Brabenec - Černá 1991). K pánvím z lokality Grillenburg a Pockau (podkrušnohorské Sasko) uvádí M. Brabenec (1988) hodnoty $1300-1350{ }^{\circ} \mathrm{C}$. V souvislosti s pánví z lokality Grillenburg byl popsán i střep, a to jako makroskopicky méně kvalitní, značně porézní. To potvrdila i data měření nasákavosti, kdy byla stanovena hodnota $12,2 \%$, jež je oproti vzorkům z Jilmové mnohem vyšší (hodnoty u pánví ze skláren Jilmová byly v rozmezí 1,9-8,6\%).

\section{Závěr}

Sklárny objevené na katastru dnes již neexistující obce Jilmová, okr. Chomutov patří k nejstarším sklářským výrobním centrům na území ČR. Archeologické výzkumy realizované v 80. letech 20. století především na sklárně Jilmová I a II významně obohatily pramennou základnu ke studiu středověkého sklářství. Kromě archeologie přispívá k poznání domácího sklářského řemesla z technologického hlediska významnou měrou také archeometrie. V předložené studii jde především o spolehlivější definici chemického typu skel vyráběných v tamějších sklárnách. Od výsledků archeometrického výzkumu se současně očekávalo, že umožní zpřesnit interpretaci jednotlivých sklářských pecí i podobu sklárny Jilmová I. a v konečném výsledku přispěje k potvrzení hypotézy o organizaci výroby skla na počátku 
vrcholného středověku. Ta předpokládá nejen existenci skláren minimálně dvojího typu (hlavní, tzv. mateřské, a vedlejší, tzv. dceřiné), ale též jejich vzájemnou kooperaci při výrobě skla z primárních surovin (viz Černá 2003, 57-62).

Z uvedených důvodů bylo záměrem předložené práce kriticky zhodnotit, jak lze pracovat s indikátory výroby skla a do jaké míry jsou výsledky analýz jejich chemického složení použitelné, co se týče určení chemického typu skla. Jako klíčové při studiu tohoto typu materiálu lze jednoznačně označit vrstvy skel ulpělé na vnitřním povrchu pánví, přestože jejich analýzy mohou být zkresleny $\mathrm{v}$ textu popsanými faktory.

V rámci této studie se podařilo určit chemické složení skla taveného v 2. pol. 13. století v dané lokalitě. Sklo lze označit jako popelové draselno-vápenaté, jehož analogii lze nalézt např. v sousedním Německu (typ skla označovaného jako wood ash glass). Metodou LA-ICP-MS bylo možno stanovit i složky ve stopovém množství, které jsou spojovány právě s vneseným popelem. Přítomnost kapek skelného vzhledu na nalezišti je pro archeologa důležitým vodítkem při prospekci a určení sklárny. Prokázalo se nicméně, že z chemického hlediska je složení těchto kapek či slitků značně variabilní a spíše neodpovídá sklu, které bylo reálně zpracováváno. Tento závěr potvrzují i zahraniční studie s obdobnými zjištěními.

Poděkování autorů patři Grantové agentuře České republiky za to, že předložená studie mohla být vypracována v rámci výzkumného projektu č. 19-23566S: Prehistorické a historické sklo z České republiky. Kontinuita dialogu archeologie a archeometrie.

\section{Literatura}

Adlington, L. W. - Freestone, I. C. - Kunicki-Goldfinger, J. J. - Ayers, T. - Gilderdale Scott, H. 2019: Regional patterns in medieval European glass composition as a provenancing tool. Journal of Archaeological Science 110, 104991. doi:https://doi.org/10.1016/j.jas.2019.104991.

Brabenec, M. 1988: Rozbory žárovzdorných materiálů z archeologických nálezů skláren v severních Čechách. In: Historie sklářských technologií únor 1988 Most, Ústí nad Labem: Dům techniky ČSVTS, 120-125.

Brabenec, M. - Černá, E. 1991: Chemicko-technologické rozbory středověkých sklářských pánví. Acta universitatis Nicolai Copernici. Archeologia XIX, 223, 89-96.

Cílová, Z. 2008: Složení historických skel a studium jejich technologie. Doktorská disertační práce, VŠCHT Praha.

Cílová, Z. - Hulínský, V. 2004: Medieval glassworks and the glass production in north-western Bohemia. Glass Science and Technology 77C, 359-363.

Cílová, Z. - Woitsch, J. 2012: Potash - A key raw material of glass batch for Bohemian glasses from $14^{\text {th }}-17^{\text {th }}$ centuries?. Journal of Archaeological Science 39, 371-380. doi: 10.1016/j.jas.2011.09.023

Čepela, P. 1989: Výsledky geofyzikálních měření na místech zaniklých středověkých skláren. In: V. Hašek ed., Geofyzika v archeologii a moderní metody terénního výzkumu a dokumentace, Brno: Geofyzika Brno a Archeologický ústav ČSAV, 49-64.

Černá, E. 1988: Počátky výroby skla v Čechách - vývoj technologie do konce 15. století. In: Historie sklářských technologií únor 1988 Most, Ústí nad Labem: Dům techniky ČSVTS, 9-17.

Černá, E. 1989: O počátcích skla v Krušných horách. Památky - příroda - život 21/4, 112-120.

Černá, E. 1990: Ergebnisse der Erforschung mittelalterlicher Glashütten in Böhmen. In: Annales du 11e Congrès de L'Association internationale pour I'Histoire du Verre, Bale 29 aout - 3 september 1988, Amsterdam: Association internationale pour I'histoire du verre, 335-340.

Černá, E. 1991: Les plus anciens documents sur la fabrication du verre en Bohême. In: D. Foy - G. Sennequier eds., Ateliers de verriers de I'antiquité à la période pré-industrielle. Actes des $4{ }^{\text {èmes }}$ Rencontres. Rouen 24-25 november 1989, Rouen: Association Francaise pour I'archéologie du verre, 103-108. 
Černá, E. 1995: Beitrag der Archäologie für Erkenntnis der Glasöfenkonstruktion im Zeitraum des Hochmittelalter. AUNC. Archeologia XXII - Nauki humanisticzno-spoleczne, zeszyt 275, 33-50.

Černá, E. 1996: Die hochmittelalterliche Glaserzeugung im östlichen Teil des Erzgebirges. In: A. Jockenhövel Hrsg., Bergbau, Verhüttung und Waldnutzung im Mittelalter, Auswirkungen auf Mensch und Umwelt, Stuttgart: Franz Steiner Verlag, 173-180.

Černá, E. 1998: Komunikační sít v SV části Krušných hor v období vrcholného středověku a její kontext s polohami sklářských hutí. Archaeologia historica 23, 97-110.

Černá, E. 2003: Neue Belege für die mittelalterliche Glaserzeugung im nordwestlichen Böhmen. In: P. Steppuhn Hrsg., Glashütten im Gespräch. Berichte und Materialien vom 2. internationalen Symposium zur archäologischen Erforschung mittelalterlicher und frühneuzeitlicher Glashütten Europas, Lübeck: Kulturkreis Glashütten, Königstein, 57-62.

Černá, E. 2016: Středověké sklárny v severozápadních Čechách. Př́nos archeologie k dějinám českého sklářství - Mittelalterliche Glashütten in Nordwestböhmen. Beitrag der Archäologie zur Geschichte des böhmischen Glashüttenwesens, Most: Ústav archeologické památkové péče severozápadních Čech Archeologický ústav AV ČR, Praha.

Černá, E. 2017: $13^{\text {th }}-14^{\text {th }}$ century glass in northwest Bohemia: typology, archaeometry and provenance.

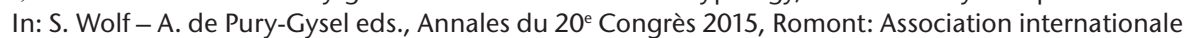
pour I'histoire du verre, 379-384.

Černá, E. - Klír, T. 2014: Osídlení Krušných hor v mladším středověku a raném novověku. Kontext a cíle interdisciplinárního výzkumu - The Settlement of the Ore Mountains in the later Middle Ages and Early Modern Period. The Context and Objectives of Interdisciplinary Research. In: I. Boháčová - P. Sommer eds., Středověká Evropa v pohybu. K poctě Jana Klápště, Praha: Archeologický ústav AV ČR, 105-118.

Černá, E. - Lissek, P. - Plachý, P. 2018: Středověká sklárna ve východním Krušnohoří na katastru Nového Města, okr. Teplice. In: E. Černá - J. Špaček eds., Historické sklo 6, Most: Ústav archeologické památkové péče severozápadních Čech, 83-103.

Černá, E. - Velímský, T. 1993: Česko-saské kontakty a problematika středověkých cest přes Krušné hory a Děčínské stěny. In: Acta Universitatis Purkynianae - Philosophica et Historica I, Ústí n. L.: Univerzita J. E. Purkyně, 359-371.

Degryse, P. - Shortland, A. J. 2020: Interpreting elements and isotopes in glass. A review. Archaeometry 62, 117-133. doi: https://doi.org/10.1111/arcm.12531

Dungworth, D. 2008: Glass-ceramic reactions in some post-medieval crucibles: An instrumental analysis study of archaeological samples. Glass Technology 49/4, 157-167.

Eramo, G. 2006: The glass-melting crucibles of Derrière Sairoche (1699-1714 AD, Ct. Bern, Switzerland): a petrological approach. Journal of Archaeological Science 33, 440-452. doi: 10.1016/j.jas.2005.09.002

Fenzi, F. - Lerma, S. - Mendera, M. - Messiga, B. - Ricardi, M. P. - Vigato, P. A. 2013: Medieval Glass-Making and -Working in Tuscany and Liguria (Italy). Towards a Standard Methodology for the Classification of Glass-Making and Glass-Working Indicators. In: K. Janssens ed., Modern Methods for Analysing Archaeological and Historical Glass, West Sussex: Wiley, 473-513.

Geilmann, W. 1954: Beiträge zur Kenntnis alter Gläser III. Glastechnische Berichte 27, 456-459.

Gerber, Ch. -Gerber, Y. - Stern, W. B. - Kaiser, L. - Eramo, G. 2012: Court, Pâturage de I'Envers. Une verrerie forestière jurassienne du début du $18^{e}$ siècle. Des matières premières aux productions. Volume 2 , Approches historiques, techniques et archéométriques. Berne: Service archéologique du canton de Berne.

Hejdová, D. - Nechvátal, B. 1967: Studie o středověkém skle v Čechách (Soubor z Plzně, Solní ul.). Památky archeologické 58, 433-498.

Himmelová, Z. - Měřnský, Z. 1987: Objekt s doklady výroby a distribuce šperkařských výrobků na hradisku „Vysoká zahrada" u Dolních Věstonic (okr. Břeclav) In: J. Merta ed., Zkoumání výrobních objektů a technologií archeologickými metodami, Brno: Technické muzeum v Brně, 129-134.

Jackson, C. M. - Booth, C. A. - Smedley, J. W. 2005: Glass by design? Raw materials, recipes and compositional data. Archaeometry 47, 781-795. doi: https://doi.org/10.1111/j.1475-4754.2005.00232.x

Jackson, C. M. - Smedley, J. W. 2008: Theophilus and the Use of Beech Ash as a Glassmaking Alkali. In: M. Martinón-Torres - T. Rehren eds., Archaeology, History and Science. Integrating Approaches to Ancient Materials, Archaeology, London: Routledge, 117-130.

Jiř́k, F. X. 1934: Kniha o skle. Praha: Jan Štenc. 
Jonášová, Š. 2016: Chemický průzkum skel I, Moldava I. Závěrečná zpráva. Ms. depon. in Oddělení archeologie středověku Archeologického ústavu AV ČR Praha.

Kubát, J. - Gelnar, M. 1991: Zhodnocení historických vzorků pánví z Lužických hor. In: Historické sklo 1, sborník pro dějiny skla, Čelákovice, Plzeň: Sklářská odborná sekce pro dějiny skla při ČAS, 45-49.

Kurzmann, P. 2004: Mittelalterliche Glastechnologie. Doktorská disertační práce, Frankfurt am Main.

Levý, O. - Čepela, P. - Zaw Win - Černá, E. 1987: Magnetometrický výzkum sklářských hutí v Krušných horách. In: J. Tirpák ed., Archeológia - geofyzika - archeometria. Acta interdisciplinaria archaeologica V, Nitra: Archeologický ústav Slovenskej akadémie vied, 42-52.

Mareš, F. 1893: České sklo: Př́spěvky k dějinám jeho až do konce XVIII. století. Se zvláštním ohledem na jižní Čechy. Praha: Nákladem České akademie císaře Františka Josefa pro vědy, slovesnost a umění.

Mendera, M. - Fenzi, F. - Galgani, M. - Giannichedda, E. - Guerriero, P. - Lerma, S. - Messiga, B. - Ricardi, M. P. Vigato, P. A. 2005: Archaeology of glass: medieval and renaissance production in Italy. Characterization and classification of production indicators: an interdisciplinary approach. In: J. W. Arrowsmith ed., Annales of $16^{\text {th }}$ Congress of the AIHV, London: Association internationale pour l'histoire du verre, 223-226.

Messiga, B. - Ricardi, M. P. - Rebay, G. - Basso, E. - Lerma, S. 2004: Microtextures recording melting history of a medieval glass cake. Journal of Non-Crystalline Solids 342, 116-124. doi:10.1016/j.jnoncrysol.20 04.06.009

Müller, K. 2006: Farbloses Glas im Wandel der Zeit materialanalytische Untersuchungen an farblosen Gläsern des 13. bis 17. Jahrhunderts mit Hilfe der Laser induced breakdown spectroscopy und der MikroRöntgenfluoreszenzanalyse. Dissertation, Technische Universität Berlin. Berlin: Mensch-und-BuchVerlag.

Paynter, S. - Dungworth, D. 2018: Archaeological Evidence for Glassworking. Guidelines for Recovering, Analysing and Interpreting Evidence. Historic England 2018. Swindon: Historic England.

Sedláčková, L. -Zapletalová, D. 2012: Skleněné kroužky z Brna a problematika raně středověkého sklářství na Moravě. Archeologické rozhledy 64, 534-548.

Selner, F. ed., 1862: Statistische Tafeln des Sebastiansberger Bezirkes. Prag.

Smedley, J. W. - Jackson, C. M. 2002: Medieval and post-medieval glass technology: batch measuring practises. Glass Technology 43, 22-27.

Smrček, A. a kol. 2008: Tavení skla. Jablonec nad Nisou: Česká sklářská společnost.

Stephan, H.-G. 1988/89: Archäologische Ausgrabung im Bereich einer hochmittelalterlichen Waldglashütte im Bramwald, Gemeinde Niematal, Kr. Göttingen. Zeitschrift für Archäologie des Mittelalters 16/17, 123-154.

Stephan, H.-G. 2020: Neue Erkenntnisse zur Mehrstufigen Mittelalterlichen Glasproduktion: „Ein-Ofen-Anlagen" im Weserbergland. In: K. Tomková - N. Venclová eds., Krajinou archeologie, krajinou skla. Studie věnované PhDr. Evě Černé, Most - Praha: Ústav archeologické památkové péče severozápadních Čech - Archeologický ústav AV ČR, 125-140.

Stern, W. B. - Gerber, Y. 2004: Potassium-calcium glass: New data and experiments. Archaeometry 46, 137-156. doi: 10.1111/j.1475-4754.2004.00149.x

Stern, W. B. - Gerber, Y. 2009: Ancient potassium-calcium glass and its raw materials (wood-ash, fern-ash, potash) in Central Europe. Mitteilungen der Naturforschenden Gesellschaften beider Basel 11, 107-122. doi: http://doi.org/10.5169/seals-676535

Velímský, T. 1998: Trans montes ad fontes! (Přes hory k pramenům!). K roli újezdů při středověké kolonizaci středních a vyšších poloh na území severozápadních Čech. Most: Ústav archeologické památkové péče severozápadních Čech.

Wedepohl, K. H. 1997: Chemical composition of medieval glass from excavations in West Germany. Glastechnische Berichte / Glass Science and Technology 70/8, 246-255.

Wedepohl, K. H. - Simon, K. 2010: The chemical composition of medieval wood ash glass from Central Europe. Chemie der Erde - Geochemistry 70, 89-97. doi: 10.1016/j.chemer.2009.12.006

Wilke, D. - Stephan, H.-G. 2020: Early to high medieval glass houses in the Upper Weser region, Germany. 26th EAA Virtual Annual Meeting.

Zavřel, J. 2003: Skláři v pražském podhradí?. Archeologické rozhledy 55, 718-735. 


\section{The glass production area near Jilmová in the Ore Mountains from the second half of the $13^{\text {th }}$ century The contribution of analytical methods for studying glass production technology in medieval Bohemia}

Until the beginning of the High Middle Ages, the glass workshops existing in Bohemia and Moravia produced only small glass ornaments (beads and rings) from imported raw glass, i.e., they were secondary production centres (cf. Himmelová - Měř́nský 1987, 129-134; Sedláčková - Zapletalová 2012, 542; Zavřel 2003, 718-735). Glassworks producing glass from primary raw materials are archaeologically documented since the middle of the $13^{\text {th }}$ century in borderland mountain areas, with one of the best studied being the Ore Mountains (Krušné hory), specifically the eastern part of this massif in northwest Bohemia, where at least six independent production areas, all in the proximity of long-distance routes running to neighbouring Saxony, have been identified to date (Černá 2016, fig. 122). One of the oldest is located in the upper parts of the mountains belonging to the district of Chomutov, in the cadastral territory of the now defunct village of Jilmová. It consists of three glassworks located on the slopes of Skelný vrch (fig. 1), near the western branch of the long-distance route mentioned in written sources as early as 1143 as a semita bohemica heading from inland Bohemia to the Chemnitz area (cf. Černá - Velímský 1993; Černá 1998). The glassworks were discovered and investigated after the mid-1980s.

The greatest number of finds are from the Jilmová I site, where the production area has been investigated in its entirety. The find assemblage from the Jilmová II glassworks is significantly smaller, as only an investigation was performed by means of a small trench at the place of two production features revealed by magnetometric survey. A similarly small number of finds are available from the third glassworks, Jilmová III, whose area was destroyed during work connected with forest planting. The results of the excavations have been published since the 1980s, focused on the typology and morphology of archaeological sources (Černá 1988; 1989; 1991). The processing of finds, especially fragments of technical ceramics (pots and crucibles) and specific waste from various stages of glass production, also raised questions about the technology of glass production. The assortment of the local glassworks remained unidentified, both in terms of the types, forms and chemical composition of the glass produced (Černá 2016, 65-92).

For these reasons, scientific analytical methods were soon used to evaluate the finds. They were first applied in the classification of technical ceramics in order to determine the physical and chemical properties of heat-resistant pots and to define the quality of these glassmaking accessories (Brabenec-Černá 1991). Later, with the development of archaeometric research, they were also focused on waste materials from the melting phase of glass production. Two assemblages (varying in size) of waste glass and technical ceramics samples were examined by X-ray fluorescence (XRF), X-ray diffraction (XRD) and scanning electron microscopy (SEM-EDS) methods (Cílová - Hulínský 2004; Cílová 2008). Since 2016, other glass has been analysed - melted glass lumps most likely from the processing phase of glass production. The SEM-EDS method was initially used, later the method of laser ablation with inductively coupled plasma mass spectrometry (LA-ICP-MS) was applied to both these and some other previously analysed samples.

It was assumed that archaeometric research would make it possible to solve previously unanswered questions, in particular to more reliably define the chemical type of glass produced at the Ore Mountains glassworks. At the same time, the results were expected to contribute to a more precise interpretation of individual glass furnaces at the Jilmová I glassworks, to the determination of the specific type of glassworks in this case and, ultimately, to confirm the hypothesis of glass production organisation at the beginning of the High Middle Ages. In the analytical part of the text, heterogeneous pieces of material found in the places of the production buildings, layers of glass stuck to melting pots, the pots themselves and small glass finds in the form of drops are evaluated. Attention was paid to the treatment of samples, which were prepared in the form of powders for the XRF and XRD methods. In the case of smaller drop samples $(\mathrm{c} .1 \mathrm{~cm})$, the samples were only lightly ground and polished. 
This less destructive sampling was used when measurements were taken using the SEM-EDS and LA-ICP-MS methods. At the same time, the contribution of the LA-ICP-MS method in solving technological issues was discussed, especially the usability of some elements to determine the raw materials used.

Some of the analysed samples were highly heterogeneous pieces of material. Use of the XRF method helped determine that these samples can be divided into two groups with a different $\mathrm{Al}_{2} \mathrm{O}_{3}$ and $\mathrm{CaO}$ content (Cílová 2008). The first group with relatively high $\mathrm{Al}_{2} \mathrm{O}_{3}$ values (above 8 wt $\%$ ) and a rather low alkali content $(\mathrm{CaO}$ content max. $7 \mathrm{wt} \%)$ represents materials randomly formed during the melting process and which cannot be described as the final products of glass production (the prevailing crystal phase was quartz and leucite $-\mathrm{KAlSi}_{2} \mathrm{O}_{6}$ ). The second group with a lower $\mathrm{Al}_{2} \mathrm{O}_{3}$ content and a higher alkali content is represented by sample no. 1991 (tab. 9). A visually similar inhomogeneous mass was also found on the inner surface of some pots (fig. 9). Beneath the heterogeneous opaque brown layer are residues of a glassy mass. The layers of glass on the inner surface of the pots were also examined, though it was necessary to take into account the contamination of the glass with the material of the pots - mainly in the form of $\mathrm{Al}_{2} \mathrm{O}_{3}, \mathrm{SiO}_{2}$ and $\mathrm{Fe}_{2} \mathrm{O}_{3}$, or other components from the heat-resistant material. Three types of glass layers clearly differing in colour and thickness were identified.

At least two variants of potash-lime glass were melted at the site and can be distinguished according to the major $\mathrm{K}_{2} \mathrm{O}-\mathrm{CaO}-\mathrm{SiO}_{2}$ components. The LA-ICP-MS method detected in them trace amounts of components that are characteristic of glass with ash, specifically these elements: $\mathrm{Sr}, \mathrm{Rb}$, $\mathrm{Zn}, \mathrm{Ni}, \mathrm{Cu}, \mathrm{Ba}$ and $\mathrm{Mn}$. An important marker in the use of ash is strontium, if it is in the order of several hundred to one-thousand ppm (Degryse - Shortland 2020). This means that the glass produced in the glassworks of the Jilmová production circle in the second half of the $13^{\text {th }}$ century can be described as wood ash glass, the chemical composition of which is analogous to glass from neighbouring Germany (wood ash glass; cf. Wedepohl 1997; Wedepohl - Simon 2010). It was also shown that small drops with a glassy appearance and which are specific to the production environment have a highly variable chemical composition inconsistent with final glass (similarly in Paynter - Dungworth 2018; Wilke - Stephan 2020).

English by David J. Gaul

EVA ČERNÁ, Archeologický ústav AV ČR, Praha, v. v. i., Letenská 4, CZ-110 00 Praha 1; cerna@uappmost.cz VERONIKA FALTUSOVÁ, Ústav chemie, Prírodovědecká fakulta, Masarykova univerzita, Kamenice 5, CZ-62500 Brno; nikadilli@gmail.com TOMÁŠ VACULOVIČ, Ústav chemie, Přírodovědecká fakulta, Masarykova univerzita, Kamenice 5, CZ-62500 Brno; vaca@mail.muni.cZ ZUZANA ZLÁMALOVÁ CílOVÁ, Vysoká škola chemicko-technologická v Praze, Technická 5, CZ-160 00 Praha; cilovaz@vscht.cz 